\title{
THE DEVELOPMENT OF A HEALTHCARE INNOVATION ADOPTION READINESS ASSESSMENT TOOL (HIARAT)
}

\author{
E. Leonard ${ }^{1}$, I.H. de Kock ${ }^{1 *}$ \& W. Bam ${ }^{1}$
}

\section{ARTICLE INFO}

\section{Article details}

Submitted by authors 24 Jun 2018 Accepted for publication 28 Mar 2019 Available online 29 May 2019

\section{Contact details}

* Corresponding author imkedk@sun.ac.za

\section{Author affiliations}

1 Department of Industrial Engineering, Stellenbosch University, South Africa

DOI

http://dx.doi.org/10.7166/30-1-2013

\section{ABSTRACT}

A disconnect exists between innovations and the adoption of such innovations, specifically within healthcare facilities. This disconnect results in various healthcare challenges - ones that could be addressed by successfully adopting and integrating an innovation into organisational processes - not being addressed. To address the challenge of innovation adoption within healthcare, it is proposed that a tool be developed to identify areas that should be addressed to improve the chances of the successful adoption and integration of innovations into existing systems in a public healthcare facility. By assessing a facility's readiness for innovation adoption, it is possible to identify the barriers to the successful adoption of innovations. Knowing what such challenges or barriers to innovation adoption are will allow role players to address these challenges or barriers. The purpose of this paper is to develop the healthcare innovation adoption readiness assessment tool (HIARAT), which measures the maturity of a healthcare facility's innovation adoption process. The HIARAT was validated through a face validation workshop, and through a case study at a South African public healthcare facility.

\section{OPSOMMING}

'n Ontkoppeling bestaan tussen innovasies en die aanneming van sulke innovasies, spesifiek binne gesondheidsorgfasiliteite. Hierdie ontkoppeling lei tot verskillende gesondheidsorguitdagings wat tans nie aangespreek word nie, maar wat aangespreek behoort te kan word deur die suksesvolle aanneming en integrasie van ' $n$ innovasie in organisatoriese prosesse. Om die uitdaging van innovasieaanneming binne gesondheidsorg aan te spreek, word voorgestel dat ' $n$ instrument ontwikkel word om gebiede te identifiseer wat aangespreek moet word om die kanse van die suksesvolle aanneming en integrasie van innovasies in bestaande stelsels in ' $n$ openbare gesondheidsorgfasiliteit te verbeter. Deur die beoordeling van ' $n$ fasiliteit se gereedheid vir innovasie aanneming, is dit moontlik om die struikelblokke tot die suksesvolle aanneming van innovasies te identifiseer. Om te weet wat sulke uitdagings of hindernisse vir die aanneming van innovasies is, sal rolspelers in staat stel om hierdie uitdagings of hindernisse aan te spreek. Die doel van hierdie artikel is om die gesondheidsorg-innovasie-aannemingsgereedskapassesserings-instrument (HIARAT) te ontwikkel, wat die volwassenheid van 'n gesondheidsorgfasiliteit se aannemingsproses meet. Die HIARAT is gevalideer deur middel van ' $n$ gesigs-evaluasie werkswinkel, en deur middel van ' $n$ gevallestudie by ' $n$ SuidAfrikaanse openbare gesondheidsorgfasiliteit. 
Healthcare in South Africa faces many challenges, and is in need of major improvements [1]. These challenges include the quality of care being provided, health inequities (public healthcare versus private healthcare), rising costs, an ageing population, and managerial and operational weaknesses [2]. Nonetheless, South Africa has made significant progress in healthcare since 1994, including legislative and policy frameworks that allow for a single integrated health system [2], an essential drugs programme, free primary healthcare, and a better immunisation programme [3].

Globally, and in South Africa, there have been significant advances in healthcare research and technologies over the past few years, and large amounts of money have been allocated to research and development in the industry. In the 2015/16 financial year, the South African government spent R 11.3 billion on research and development across all sectors, 18.1 per cent of which was spent on healthcare-related research and development [4].

However, innovative solutions developed to improve aspects of healthcare frequently are not implemented at the facilities where they are needed [5]. The literature suggests that the adoption of these solutions in practice is hindered by a number of challenges. A need thus exists to evaluate the healthcare system, and more specifically healthcare facilities, with the aim of identifying the barriers and limitations to innovative solution adoption. Such an evaluation will allow healthcare managers to address the factors that hinder the successful adoption and integration of innovative solutions at their facilities, ensuring that the system is conducive to the adoption of innovations. The development of an 'innovation readiness' assessment tool will contribute towards more effectively achieving such assessments.

The research objectives that supported the aim of this investigation were:

1. To review the literature addressing the healthcare landscape in South Africa, current strategies for managing innovation, and innovative solution adoption in the South African healthcare environment.

2. To develop an assessment tool that can be used in healthcare facilities to assess their readiness for innovation adoption.

3. To test and validate the feasibility of the developed tool by performing a field trial at a public healthcare facility.

\section{HEALTHCARE IN SOUTH AFRICA}

South Africa has made innovative medical advances due to state-funded health research; some notable achievements include the first human heart transplant and computed tomography [6]. However, since the start of the 1980s there has been a restructuring of state expenditure in the healthcare system. In 1994 specifically, the emphasis of South Africa's public healthcare services shifted towards the aim of increasing affordability and improving accessibility. This shift was accompanied by an increase in government spending on public healthcare [7], with the focus being placed on primary healthcare and "healthcare for all" [7]. Unfortunately, this has also meant a stagnation in the amount of state-funded health research [6].

Despite the apparent trade-off between innovation, increasing affordability, and improving accessibility, innovation remains a leading force in attaining the goal of minimising healthcare costs while maximising quality [8]. To innovate successfully, health research funding is necessary, in conjunction with effectively adopting healthcare innovations into appropriate sections of the national healthcare system.

Organisations tend to find the adoption of innovations difficult; the reasons for this range from the potential risks involved, to a lack of resources to carry out innovations [9]. Barriers to the adoption of innovations can be grouped into the characteristics of the organisation, the characteristics of the actual innovation, and the characteristics of the environment [10]. 
Innovation is centred on processes and principles that are necessary for an invention to be developed into an innovation that will then be practically implemented [9]. Multiple different innovation adoption processes have been described by authors. These include the processes proposed by Rogers [11], Van Zyl [12], Hoffman [13], Kim [14], Ehigie and McAndrew [15], and Tidd and Bessant [10]. In order to choose an innovation process to use during the development of the HIARAT, the number of citations and the date of publication for each author's innovation process were considered. The top two most cited processes were proposed by Rogers [11] and Tidd and Bessant [10] ${ }^{1}$. Of these two processes, Tidd and Bessant [10] were published in 2009, whereas Rogers [11] was published in 2003. Tidd and Bessant's [10] model was considered to cover the innovation adoption process effectively; and, because it had the second highest number of citations and was published more recently, the decision was made to use this innovation adoption model during the development of the HIARAT. However, it should be noted that this innovation adoption process element of the HIARAT can be changed or updated for future versions of the HIARAT, if deemed necessary for the tool's improvement.

Tidd and Bessant's [10] model of the innovation adoption process (Figure 1) shows the innovation adoption process from an organisation's perspective, looking to incorporate innovative opportunities. (These innovations can come from internal or external sources.)

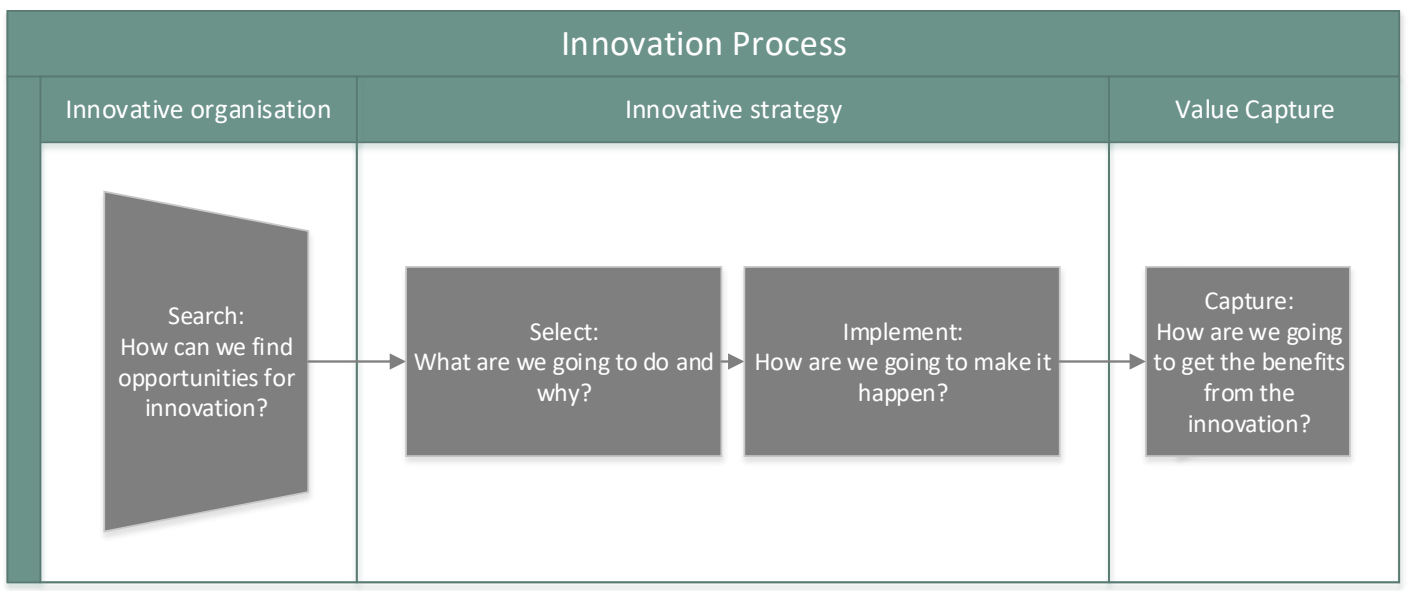

Figure 1: Process model of the innovation adoption processes within an organisation [10]

The first phase of the innovation process model (search) consists of finding areas in the organisation's environment where there is potential for change [10]. When managing the adoption process of an innovation in an organisation, the trigger or source of the innovation should be considered [10]. Triggers of innovation will influence the first phase of the innovation process model. Triggers of innovation can be influenced by multiple factors, including new markets, technologies, political rules, and public opinion [10].

Phase two (select) consists of the organisation weighing the risks and rewards to determine which innovations to pursue [10]. The third phase (implement) involves the organisation making the innovation a reality at its facility [10]. The goal of the innovation process is to derive some form of value from these innovations. The final phase (capture) entails encapsulating value from the innovation and, if the innovation fails, the reasons for failure [10]. The result of any process is the collective outcomes of participants or role players at each level [16].

1 This was determined by considering the number of citations Rogers [11], Van Zyl [12], Hoffman [13], Kim [14], Ehigie \& McAndrew [15] and Tidd \& Bessant [10] each had on Google Scholar for the papers in which they described the innovation process (refer to the list of references for the papers that were considered) at the time of writing this article. 


\subsection{Role players in the innovation process}

Essentially, innovation is about people [9]. Rothwell [17] identified having certain key individuals present as a characteristic of successful innovation. The central role players in an organisation's innovation process can be identified as the following:

i. The networker, who studies trends within technology, society, markets, and regulations to recognise opportunities. The networker is also responsible for creating connections with external organisations, or with individuals who have corresponding objectives [18]. The networker is also known as the technological gatekeeper [17]. The networker is active in Phase 1 - the search phase;

ii. The co-ordinator, who ensures that projects' resources, objectives, and risks are balanced; and will promote concepts and opportunities. The co-ordinator must schedule, prioritise, and guarantee project completion through overcoming the obstacles that are faced [18]. The coordinator will be active in Phases 2, 3, and 4 - the selection, implementation, and capture phases;

iii. The builder, who creates, demonstrates, and defines tangible concepts; the builder will ensure that the product or service is ready to be supplied to the customer [18]. The builder will be active during Phase 3 - the implementation phase;

iv. The anthropologist, who must have an understanding of people's interactions (both emotional and physical) with services, products, their environment, and with other people. The anthropologist can anticipate stakeholders' needs and is able to influence people's attitudes and behaviours [18]. The anthropologist will be active during Phases 2 and 3 - the selection and implementation phases;

v. The product champion [17] or leader, who ensures that the organisation's activities are aligned with its objectives and strategies. The leader will prioritise opportunities to implement and will monitor a project's metrics [18]. This person is committed to the implementation of the innovation, and is able to push the project through the internal barriers [17]. The product champion will be active during phases 2,3 , and $4-$ the selection, implementation, and capturing phases.

\subsection{Measuring innovation}

The innovation performance of organisations has been extensively studied [19], because organisations recognise the value of innovations. However, the majority of metrics that have been studied tend to be for an organisation looking to incorporate innovation into its culture and develop innovative ideas, rather than to measure its ability to adopt an innovation (regardless of the source of the innovation). Hagedoorn and Cloodt [19] identified four indicators that are used to measure an organisation's innovative performance: research and development inputs, patent citations, patent counts, and new product announcements. From Hagedoorn and Cloodt's indicators, it can be speculated that the term 'innovative performance' refers to an organisation's ability to develop innovative concepts and ideas, but not necessarily its performance when adopting innovations. The innovation capability maturity model, which is based on the capability maturity model [18], can be useful in measuring an organisation's innovation ability throughout the stages of the innovation lifecycle. It is not limited to the measurement of an organisation's ability to produce innovative ideas or an innovative culture.

A capability maturity model (CMM) is a technique that determines how mature an organisation is, by comparing the organisation's processes and the methods used in these processes against structured levels that represent how reliably an organisation can sustain the desired outcomes [20]. A CMM allows an organisation to understand their current position in comparison with the best practices in a specific domain (e.g., innovation); the capability maturity gives the organisation an indication of what direction it should go in to improve its outcomes in a specific domain [20]. A maturity model shows what needs to be improved, but does not show how the improvement should take place [21]. The model helps an organisation set improvement priorities and objectives [21]. CMMs are used across many different industries, and for many different applications [20]. Despite the large number of domains where the maturity model has been applied, the objectives and structures of the models remain very similar [22] [20]. Maturity models are often used to aid the improvement of complex systems or concepts [22]. 
The levels that are used in maturity models define an evolutionary pathway to an ideal process at the highest maturity level [21]. CMMs tend to have the same five levels [20], which, as described by the capability maturity model integration, are [23]:

Level 1: Initial (ad-hoc): in this level, the process is unpredictable and badly controlled;

Level 2: Managed: in this level, processes are characterised for specific projects;

Level 3: Defined (standard): in this level, processes are characterised for the organisation;

Level 4: Quantitative (measured): In this level, processes are measured;

Level 5: Optimising: in this level, there is a focus on improvement.

When assigning an organisation to a level, it must have met the requirements of each of the previous levels [20]. The CMM has been an inspiration and the basis for the development of many other maturity models that have been developed for application in different settings and domains, including the development of the innovation capability maturity model (ICMM) [24].

\subsection{Innovation in healthcare}

Healthcare innovation is defined as the introduction and adoption "of a new concept, idea, service, process, or product aimed at improving treatment, diagnosis, education, outreach, prevention and research, and with the long-term goals of improving quality, safety, outcomes, efficiency and costs" [8]. Healthcare innovations target healthcare processes (the methods used for the production of goods or for delivery of a service), products (the goods or services that the customer pays for), or structures (business models affecting the internal and external organisation structure) [8].

In spite of substantial improvements made within the healthcare industry, there are still many inefficiencies [25]. There is no longer a problem with a lack of innovative evidence-based medical practices; the issue is that not enough of these medical innovations are successfully adopted in health facilities [5]. Even if the case for an improvement is clear, strategies that will translate the innovative solutions into practice have not been effective, properly implemented, or used. The goal is not where the point of confusion lies; the path for achieving the goal is the challenge [26].

Multiple implementation theories have been published in an attempt to support effective innovation implementations. Healthcare researchers have begun to recognise the importance of implementation science [27]. Damschroder et al. [27] have compared many of these healthcare innovation adoption theories, and have revealed that considerable overlap exists; but they state that each theory misses one or more critical constructs. Damschroder et al. [27] thus created the 'consolidated framework for implementation research' (CFIR) by consolidating the common building blocks from the various other published theories. For the purpose of this investigation, the CFIR will be analysed further, assuming that it successfully encompasses the necessary building blocks of a healthcare implementation framework (because Damschroder et al. [27] have successfully consolidated the critical aspects from the existing adoption theories). Other innovation models and frameworks that have been found during the literature analysis tend only to be applicable to creating an innovative environment within the healthcare facility, and not to dealing with innovation adoption.

\section{METHODOLOGY}

The tool selected on which to base the HIARAT was the capability maturity model (CMM). The CMM most directly correlated with the aim of assessing a facility's current state of readiness to adopt an innovation. The CMM enables the organisation being assessed to carry out an improvement process once the barriers to the innovation adoption process have been identified by the tool ${ }^{2}$ [24]. The HIARAT should be a standardised approach that can be used at any healthcare facility to identify the facility's barriers to innovation adoption; thereafter the healthcare facility can, of its own accord, carry out an improvement process suited to its challenges, needs, and resources.

2 The scope of this investigation is to develop a tool that assesses how ready a facility is for innovation adoption; the tool does not provide the organisation with an improvement process. The tool highlights areas that hinder innovation adoption, thus identifying areas in the organisation where resources should be focused to address the barriers identified by the tool. 
In order to develop the HIARAT, the general tool development process proposed by Whiting et al. [28], and the more specific developmental process for a CMM proposed by De Bruin et al. [29], were combined, as shown in Figure 2. These are the steps that were followed to develop the HIARAT.

During the preliminary conceptual phase, decisions on the scope of the tool and on the model's architecture needed to be made. Thereafter the first draft of the tool was populated through item generation. Finally, the tool was subjected to testing, which included face validation and a field trial to refine the tool.

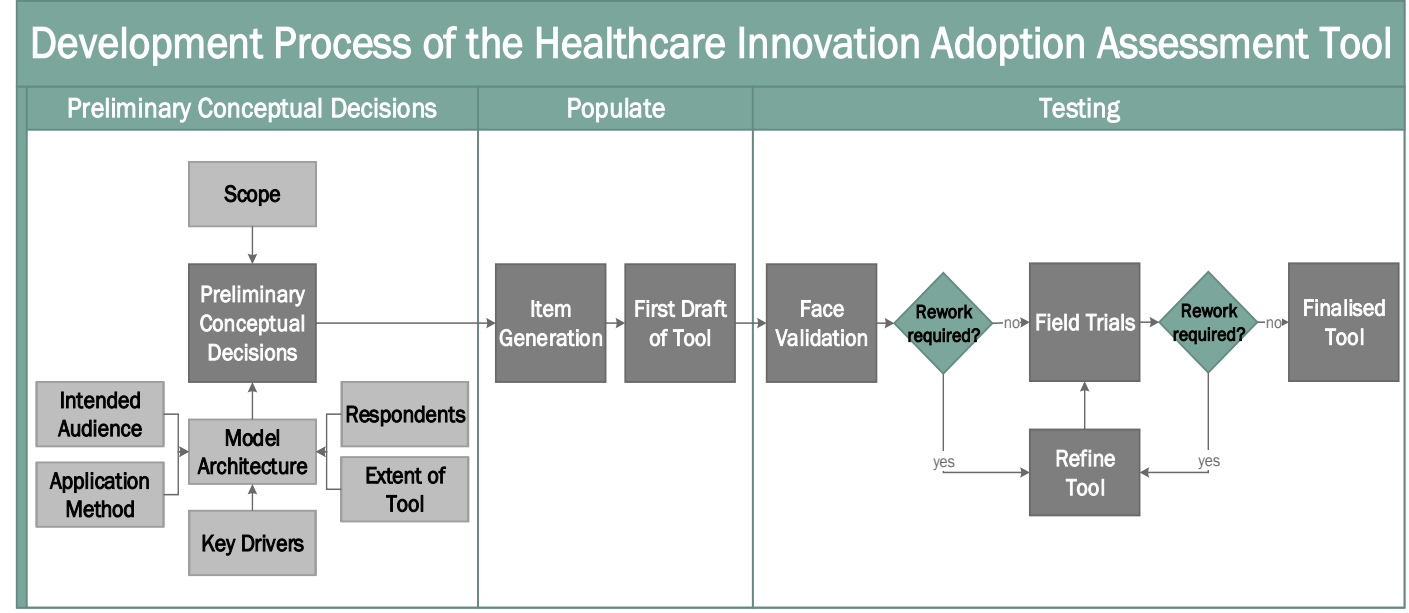

Figure 2: Combined tool development process followed to develop the HIARAT

\section{THE HEALTHCARE INNOVATION ADOPTION READINESS ASSESSMENT TOOL (HIARAT)}

The HIARAT is divided into two parts: i) the conceptual model that represents the organisation's innovation adoption readiness - i.e., the innovation adoption capability maturity level of the facility, which is shown in Figure 3; and ii) the user interface, which is used to gather the necessary information from the facility being assessed in order for the process maturity capability levels for each of the domains to be determined. The user interface is shown in Appendix A. The results from the maturity analysis allow the facility to pinpoint the areas and factors of innovation adoption process that hinder the adoption of the innovation, for each of the domains. Once the barriers and limiting factors to successful adoption and integration of an innovation have been identified, the relevant role-players can proceed to identify actions that would address these barriers and limitations to the successful adoption and integration of an innovation. The tool thus acts as a decision support system; it does not focus on proposing any improvement initiatives, but rather on the identification of barriers and challenges to the adoption of innovation.

\subsection{Conceptual tool}

The conceptual tool consists of three planes, as seen in Figure 3. The innovation adoption process axis versus the domains axis provides a description of the innovation adoption process of a specific organisation (Table 1). The maturity capability levels axis versus the domains axis provides specific maturity capability statements for each domain (Table 2 ).

The statements in the description matrix (Table 1) and in the specific domain maturity capability matrix (Table 2 ) are both used to create the user interface - the process maturity capability matrix in Figure 3. There are five domain-specific process maturity sections in this matrix that have to be filled in to determine the maturity levels. In order for the assessor ${ }^{3}$ to complete the specific domain process maturity capability matrices, information needs to be obtained from the healthcare facility whose innovation adoption readiness is being assessed. Once the information is obtained from the facility, these matrices can be used to determine the innovation adoption readiness of the organisation in each step of the innovation process and within each domain.

3 The assessor is an external body, such as a qualified industrial engineer or project manager, who assesses the readiness for innovation adoption within that facility. 
Thereafter the descriptions of the innovation adoption process for a specific domain were compared with the same domain's maturity capability level statements; Table 3 to Table 7 were then developed, showing the process maturity capability for each of the five domains, which are referred to as the user interfaces of the HIARAT.

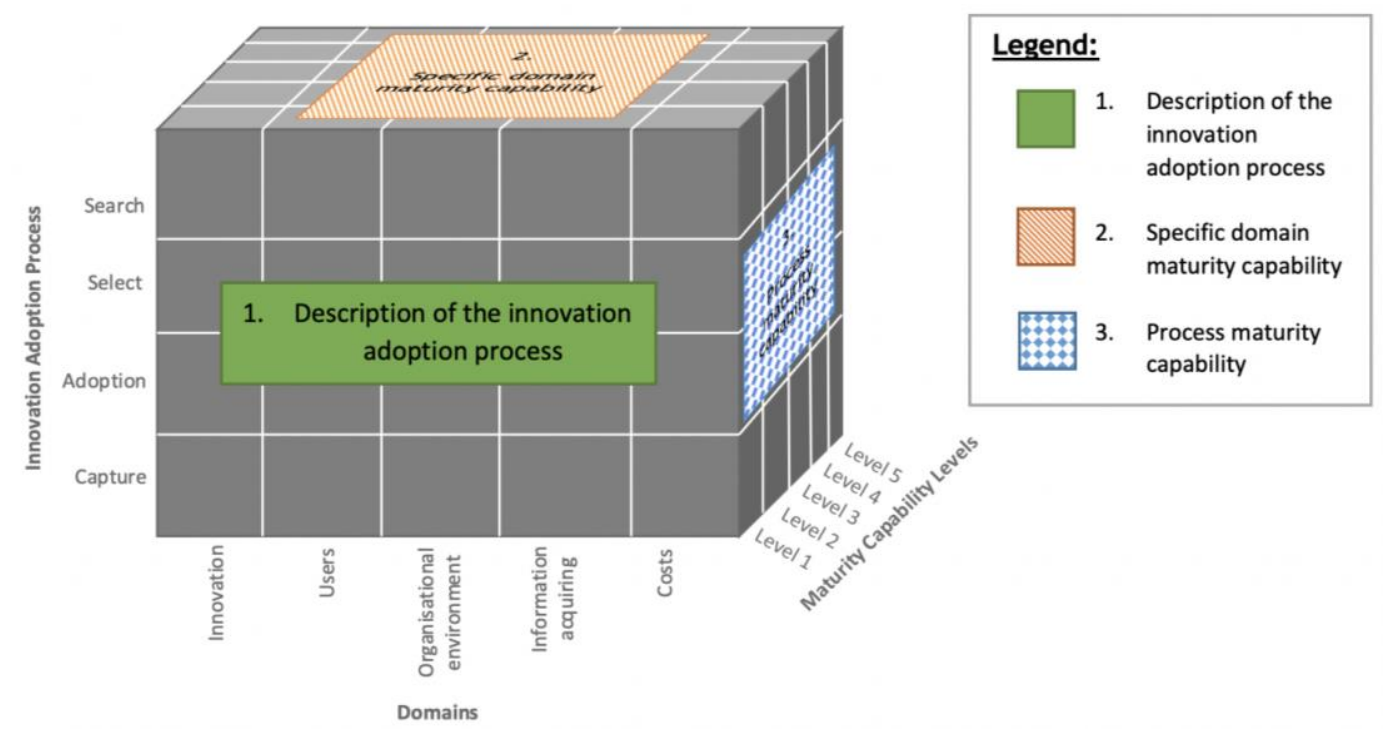

Figure 3: Conceptual framework of the HIARAT (see online version for colour)

\subsubsection{Dimension 1: Capability maturity levels}

There needs to be a way to measure the innovation adoption readiness of a healthcare facility. The general maturity levels, described by CMM and ICMM, provide an effective and descriptive way of measuring how ready the domains (which are necessary to support the innovation adoption process) are, seeing that it is difficult to measure analytically how 'innovation ready' an organisation is.

\subsubsection{Dimension 2: Innovation adoption process}

By including the innovation adoption process dimension in the HIARAT, the tool becomes more thorough in describing a healthcare facility's readiness to adopt an innovation. This is because the process dimension allows the organisation to determine what the barriers to innovation adoption are, but also in which phases of the innovation adoption process the barriers are. The innovation adoption process of an organisation is made up of five stages, as described by Tidd and Bessant [10].

\subsubsection{Dimension 3: Domains}

There are numerous variables that influence the item generation in the domain section (shown as 'Domains' in Figure 3). A domain describes a distinctive subset [30], which in this case is used to refer to a distinctive subset of the variables that affect (enable or hinder) the innovation adoption process.

In order to divide the domain items into sections ${ }^{4}$, the consolidated framework for implementation research (CFIR) was considered. This framework discusses five constructs that are critical to the innovation adoption process: the intervention characteristics, the outer setting, the inner setting, the characteristics of individuals, and the process reference [27]. The subsections of the barriers and enabling factors of innovation adoption, as described by Tidd and Bessant [10], were considered; these subsections are environmental characteristics, organisational characteristics, and characteristics of the innovation. Lastly, Van Dyk's [24] approach to determining the domains for the telemedicine service maturity model was considered. This approach was to consider the generic descriptions of the $5 \mathrm{Ms}$ of manufacturing (man, machine, method, material, and money) and align these with the telemedicine service [24].

These sections are necessary to divide the barriers and enabling variables into logical segments so that the assessment tool is more user-friendly; the capability maturity of the different domains during the innovation adoption process will vary, and this requires segmentation. 
To divide the domains into sections, each of the $5 \mathrm{Ms}$ was considered and matched to the factors from the CFIR and the innovation adoption barriers. In summary, 'machine' aligns with the characteristics of the innovation, 'man' aligns with the characteristics of individuals, 'method' corresponds with the inner organisational setting, 'material' aligns with information acquisition, and 'cost' aligns with the financial aspects of the innovation, the organisation, and the outer setting. Thus, within the HIARAT, there are five domain sections:

i. The innovation's characteristics: This domain refers to the characteristics of the innovation(s) that are being considered for adoption and integration into the organisation. The maturity of the specific innovation's characteristics being adopted into an organisation will be measured.

ii. Users: This domain includes the stakeholders that are directly involved in the innovation adoption process, as well as stakeholders of the innovation (certain stakeholders will be role players in the adoption process) $)^{5}$. Different role players are active during each phase of the innovation adoption process. The presence of specific users, and those users having an influence in the organisation, will influence the success of the innovation adoption process.

iii. The organisational environment: This is a broad domain that encompasses some of the other domains (users domain and costs domain). However, in order not to condense this domain overly, the organisational environment will include the goals and objectives of the organisation, the culture, policies, and the organisation's structure.

iv. Information acquisition: This domain includes the factors of the external environment that affect the innovation adoption process, and the information acquisition and communication that happens within the organisation.

v. Costs: This domain's variables include all the financial aspects related to adopting an innovation during each phase of the innovation adoption process.

\subsection{User interfaces}

The HIARAT's user interfaces work like a marking rubric; for each user interface, the characteristics - applicable to each of the four stages of the innovation adoption process - are marked against the maturity level that is most applicable to the facility.

The first user interface, Table 3 in Appendix A, deals with determining the innovation adoption process maturity capability given a specific innovation's characteristics. Seeing that this interface deals with a specific innovation, the assessor must determine whether the organisation has an innovation within one of the phases of the innovation adoption process. It is assumed that, if an innovation is in the adoption stage, for example, it would have gone through the preceding search and select phases. Within each stage of the innovation adoption process, there are characteristics of the innovation that have been identified, through the literature, that affect the innovation adoption process. These characteristics are measured against the five levels of maturity to determine the capability of the innovation - i.e., how well the innovation's characteristics point to adoption within the organisation. Table 3 will thus help the organisation to determine whether the innovation is ready for adoption within the organisation, and/or what areas of the innovation/organisation need to be improved so that adoption will be a success. In the event that the organisation is not considering any innovation at the time of the assessment, this domain (Table 3) will be skipped.

The second user interface, the user domain, or Table 4 in Appendix A, deals with the people who are involved in the innovation adoption process. The users in this domain include the role-players who are directly involved in the innovation adoption process, and the stakeholders of the innovation (certain stakeholders will be role-players in the adoption process). The presence of specific users who have influence and control in the organisation will influence the success of the innovation adoption process. There are central innovation role-players within each stage of an organisation's innovation adoption process. These users are measured against the five levels of maturity to determine the capability of the organisation's users to facilitate and support the innovation adoption process. Table 4 thus helps the organisation to determine whether it has the necessary role-players in the organisation, and what areas need to be improved, from management support to the role players, and their roles, influence, and power to ensure a successful innovation adoption process.

Stakeholders are different from role players; role players will have a hands-on position during the adoption process, whereas stakeholders are interested parties who influence decisions but do not necessarily have a primary role in the adoption process. A stakeholder can be a role player, and vice-versa. 
The third user interface, shown in Table 5 in Appendix A, deals with the organisational environment domain, where the innovation adoption process takes place. This interface includes the organisation's goals and objectives, and its structure, culture, and policies. The characteristics of the organisational environment are measured against the five levels of maturity to determine the capability of the organisational environment to follow and facilitate the innovation adoption process. Table 5 helps the organisation to determine what factors need to be improved to increase the effectiveness of the innovation adoption process.

The fourth user interface, Table 6 in Appendix A, deals with information acquisition throughout the innovation adoption process. The interface includes the organisation's access to information, the competitive pressures, the external policies, customer needs and resources, and the internal and external communication network. The factors influencing the organisation's information acquisition environment are, in turn, measured against the five levels of maturity to determine the capability of the organisation to acquire information during the innovation adoption process. Table 6 helps the organisation to determine what factors need to be improved for information acquisition.

The final user interface, Table 7 in Appendix A, considers all of the finances involved during each phase of the innovation adoption process. The factors influencing the organisation's financial resources are measured against the five levels of maturity to determine the capability of the organisation to fund the stages of the innovation adoption process. Table 7 helps the organisation to determine which areas of the innovation adoption process need to be better funded.

\section{VALIDATION}

In order to validate the HIARAT, a face validation and a field trial were conducted (refer to Figure 2). When testing the HIARAT through face validation, a workshop was held where two subject matter experts were consulted. After adjustments were made in accordance with the validation workshop, a field trial was carried out to test and adjust the HIARAT further, where necessary. The field trial was conducted at a public healthcare facility in the Western Cape, with the assistance of the healthcare facility's manager.

\subsection{Face validation workshop}

To conduct the face validation, two subject matter experts were consulted, during two separate face validation workshops, to determine the applicability of the developed HIARAT to evaluate the innovation adoption readiness/maturity in public healthcare facilities. The developer of the HIARAT facilitated the face validation workshops; an information pack (which included the background on why the assessment tool was developed, the aim of the assessment tool, and the objective of the HIARAT) was sent to each subject matter expert before the face validation workshops. Each subject matter expert completed a questionnaire during the workshop. The main improvements suggested during the workshops were:

i. To clarify who would be conducting the assessments;

ii. To ensure that the user interface is self-explanatory (implying that footnotes, which include definitions and explanations, should be included in the user interface);

iii. To decrease the tool's complexity by adding the statements into the user interface rather than having a separate questionnaire. (questionnaires were used to fill in the user interface for the first draft of the HIARAT.)

It should be noted that no major concerns or adjustments were suggested during the workshops; all suggestions made were deemed valuable and were incorporated into the revised HIARAT. It should also be noted that the scoring of the subject matter experts differed in a number of areas; however, even if one subject matter expert scored a certain dimension highly, and the other considered that dimension to be lacking in some areas, that specific dimension would still be addressed. All aspects of the HIARAT that were scored three or less (out of five) during the face validation workshops were addressed when creating the second draft of the HIARAT. 


\subsection{Field trial}

The second stage in testing the HIARAT was carried out as a field trial at a public healthcare facility in the Western Cape Province ${ }^{6}$. The field trial was conducted to evaluate the usability, consistency, and validity [28] of the HIARAT. During the field trial, the developer of the HIARAT acted in her capacity as industrial engineer-in-training, and facilitated the assessment process of the healthcare facility. During the field trial, the user interfaces were filled out (Error! Reference source not found. to Table 7) by discussing the relevant information with the healthcare facility's manager. This manager is a medical doctor who also takes responsibility for the general management of the facility, and hence is also knowledgeable about the innovation adoption process at that facility.

The first user interface describes the innovation adoption process maturity capability for the innovation characteristics domain, in which the facility manager considered an innovation that had already gone through the innovation adoption process: an electronic scripting system. This innovation was created in-house through the recognition of a need within the facility. This innovation scored high maturity levels (between levels 4 and 5), meaning that the characteristics of this innovation bode well for adoption within the healthcare facility.

Table 3 effectively covered the aspects of an innovation that influence the innovation adoption process.

The second user interface describes the innovation adoption process for the users' domain, in which high maturity levels were scored; during each phase of the innovation adoption process, a level 4 was scored. The meaning of the maturity levels is that there are appropriate users within the facility who ensure a successful innovation adoption process. It is recommended that the facility formalise the innovation roles and ensure that all employees are encouraged to participate in the innovation adoption process.

Table 4 effectively covered the aspects of users that influence the innovation adoption process; however, the definition of the networker will be adjusted so that it is more suitable for a public healthcare facility. It was found that the search phase of the adoption process is mostly driven by chancing upon needs within the facility, and not by people actively searching for the innovation. This is due to the limited resources available at a public healthcare facility.

The third user interface describes the innovation adoption process for the organisational environment domain; maturity levels of two to four were scored for the phases of the innovation adoption process for this domain. The range of maturity levels shows that there is room for improvement within the organisational environment domain. Ideally, the change-resistant culture within the facility should be addressed. The Western Cape Department of Health contributes to the barriers to the facility's innovation adoption process, and the organisation that is considered in the tool would include this government department because all public healthcare facilities in the Western Cape have to adhere to the goals, objectives, and values of the government department. The hierarchical structure of the organisation (which includes the healthcare facility and the Department of Health) creates obstacles to the innovation adoption process; the goals and objectives of the organisation are not clearly communicated to all personnel. And although the organisation's vision includes innovation, it is not actively encouraged. Error! Reference source not found. effectively covered the aspects of the organisational environment that influence the innovation adoption process, although there will be a slight change of wording for the descriptions of the search phase, and the organisation will be considered to include the government department, seeing that public healthcare facilities abide by its goals and objectives.

The fourth user interface describes the innovation adoption process for the information acquisition domain; maturity levels of one to four were scored for the phases of the innovation adoption process. The range of maturity levels shows that there is room for improvement within the facility's information acquisition domain. The information acquisition procedure should ideally be standardised, which would facilitate the information flow between personnel at different organisational levels, or from employees who are not clinical personnel but still work in the healthcare facility. In addition, it is proposed that project management policies be created and managed at the healthcare facility to improve the outcomes of the innovation adoption process, and to synchronise resources and activities optimally.

\footnotetext{
6 The public healthcare facility requested to remain anonymous in the written report.
} 
Table 6 effectively covered the aspects of the information acquisition domain that influence the innovation adoption process. However, the phrase 'competitive pressures' in the select phase will be replaced with 'benchmarking pressures', as there are instinctive negative connotations to the first phrase, even with the definition that explains the meaning behind the phrase.

The final user interface describes the innovation adoption process for the cost domain; maturity levels of one to two were scored for the phases of the innovation adoption process. This low range of maturity levels shows that there is room for improvement within the organisation's cost structure. The solution is thought to lie with the Department of Health; the government needs to provide the necessary funding that will support the uptake and implementation of innovations.

Table 7 effectively covered the aspects of the cost domain that influence the innovation adoption process. This table is necessary; however, in future developments, weightings will be considered, because even though costs are a factor that hinder or enable the innovation adoption process, they do not stop the innovation from progressing if the personnel involved are passionate about adopting it.

From the field trial, the conclusion can be drawn that the HIARAT is understandable by an external stakeholder at a public healthcare facility, and is effective in assessing a healthcare facility's innovation adoption readiness. This maturity model is used at the discretion of the assessor, so it could be partially biased, and it is thus suggested that training for assessors is provided to ensure as little bias as possible. The feedback received while conducting the field trial was considered to refine the HIARAT further; this refined HIARAT is presented in Appendix A.

\section{CONCLUSION}

This investigation was undertaken to develop a tool to evaluate a healthcare facility to identify barriers and limitations to innovation adoption; the HIARAT was developed from this. The outputs from applying the HIARAT support the healthcare organisation in addressing the barriers to the innovation adoption process by identifying the areas that currently act as barriers, or where challenges to innovation adoption exist.

There is much room for further research and development of the HIARAT. These improvements and research areas fall outside the scope of this investigation. Seeing that the tool is assessing the innovation adoption readiness of a specific facility, it is envisaged that some sort of value, such as an innovation readiness score, could be beneficial to healthcare facilities. This value will allow the facility to see whether there is an improvement at the healthcare facility if the assessment is done more than once. In order to come up with a single innovation readiness score for a facility, each domain would have to be weighted according to the urgency of a domain or section within the innovation adoption process. The cost dimension for a public healthcare facility would be given a lower weighting than the other four domains, due to the nature of a public healthcare facility.

The tool could be developed to become more self-explanatory, so that a manager at a healthcare facility could administer the tool without needing an external assessor and/or an industrial engineer to conduct the assessment. Methods to achieve this could be through an Excel model where options from a drop-down menu are selected, or through a free web-based application where healthcare facilities would be able to compare their innovation readiness scores with each other, creating a benchmarking system between healthcare facilities.

The population phase of the tool development process could be re-visited to conduct the assessment extensively during this phase. The method suggested by De Bruin et al. [29] could be used; this entails the use of an electronic survey that includes quantitative measures for measuring the items in the model. Re-visiting the population phase would allow the model to grow and become more effective at assessing the innovation adoption readiness of a facility. Further research could be done to expand the reach of the model to include the assessment of private healthcare facilities. The HIARAT is specifically geared towards public healthcare facilities; but the factors that drive public and private healthcare innovations are different, and these factors would affect the HIARAT. 


\section{REFERENCES}

[1] Plummer, S. 2015. Global health care country reports: South Africa. Industry Report

[2] Van Der Byl, C. 2014. Twenty year review: South Africa 1994-2014. Government of South Africa.

[3] Harrison, D. 2009. An overview of health and health care in South Africa 1994 - 2010: Priorities, progress and prospects for new gains. A Discussion Document Commissioned by Henry J Kaiser Family Foundation to Help Inform the National Health Leaders' Retreat, Muldersdrift, pp. 1-40.

[4] PATH. 2016. Health research and development budget allocations and expenditures in South Africa: A baseline report. Baseline Report, Seattle: www.path.org.

[5] Denis, J.-L., Hébert, Y., Langley, A., Lozeau, D. \& Trottier, L.-H. 2002. Explaining diffusion patterns for complex health care innovations. Health Care Management Review, 279(3), pp. 60-73.

[6] Paruk, F., Blackburn, J.M., Friedman, I.B. \& Mayosi, B.M. 2014. Health and finance: National expenditure on health research in South Africa: What is the benchmark? South African Medical Journal, 104(7), pp. 468 474.

[7] Christian, C. 2015. Universal health coverage means more than access and affordability - quality matters too. The Conversation, 2015. [Online]. Available: https://theconversation.com/universal-healthcoverage-means-more-than-access-and-affordability-quality-matters-too-49301. [Accessed: 07-Feb-2017].

[8] Omachonu, V.K. 2010. Innovation in healthcare delivery systems: A conceptual framework. The Innovation Journal, 15(1), pp. 1-20.

[9] Berg, R. 2013. The innovation maturity model. (n.p.): Berg Consulting Group Pty Ltd.

[10] Tidd, J. \& Bessant, J. 2009. Managing innovation, $4^{\text {th }}$ ed. West Sussex: John Wiley \& Sons, Ltd.

[11] Rogers, E.M. 2003. The diffusion of innovations, 5th ed. New York: The Free Press.

[12] Van Zyl, H. 2006. Innovation models and the front-end of product innovation. Master's thesis, Stellenbosch University, South Africa.

[13] Hoffmann, V. 2007. The diffusion of innovations: The Hohenheim concept. Knowledge and Innovation Management. Module reader, Hohenheim University, Germany, pp. 87-96.

[14] Kim, S.H. 1990. Essence of creativity: A guide to tackling difficult problems. New York: Oxford University Press.

[15] Ehigie, B.O. \& McAndrew, E.B. 2005. Innovation, diffusion and adoption of total quality management (TQM). Management Decision, 43(6), pp. 925-940.

[16] Smith, H. \& Fingar, P. 2003. Business process management: The third wave (Vol. 1). Tampa, FL: MeghanKiffer Press.

[17] Rothwell, R. 1992. Successful industrial innovation: Critical factors for the 1990s. R\&D Management, 22(3), pp. 221-240.

[18] Essmann, H. \& Du Preez, N. 2009. An innovation capability maturity model: Development and initial application. International Journal of Social, Behavioral, Educational, Economic, Business and Industrial Engineering, 3(5), pp. 382-393.

[19] Hagedoorn, J. \& Cloodt, M. 2003. Measuring innovative performance: Is there an advantage in using multiple indicators? Research Policy, 32(8), pp. 1365-1379.

[20] Esterhuizen, D., Schutte, C.S.L. \& Du Toit, A.S.A. 2011. Enhancing innovation capability maturity through knowledge conversion. Acta Commercii, 11(1), pp. 211-231.

[21] Jansson, K. 2011. An innovation and engineering maturity model for marine industry networks. In: $12^{\text {th }}$ IFIP Working Conference on Virtual Enterprises, pp. 253-260. Springer, Heidelberg.

[22] Blommerde, T. \& Lynch, P. 2016. A maturity matrix for assessing service innovation capability. In: Irish Academy of Management Conference Waterford Institute of Technology, pp. 1-27. Dublin, Ireland.

[23] Knoke, B. 2013. A short paper on innovation capability maturity within collaborations. In: New Generation Enterprise Business Innovation Solutions (NGEBIS) Short Papers, pp. 7-11. Valencia, Spain.

[24] Van Dyk, L. \& Schutte, C.S.L. 2013. The telemedicine service maturity model: A framework for the measurement and improvement of telemedicine services. In Telemedicine, INTECH: open science/open minds, Chapter 10: pp. 217-238.

[25] Thakur, R., Hsu, S.H.Y. \& Fontenot, G. 2012. Innovation in healthcare: Issues and future trends. Journa of Business Research, 65(4), pp. 562-569.

[26] Auerbach, A., Landefeld, S. \& Shojania, K. 2007. The tension between needing to improve care and knowing how to do it. The New England Journal of Medicine, 357(6), pp. 608-613.

[27] Damschroder, L.J., Aron, D.C., Keith, R.E., Kirsh, S.R., Alexander, J.A. \& Lowery, J.C. 2009. Fostering implementation of health services research findings into practice: A consolidated framework for advancing implementation science. Implementation Science, 4(50).

[28] Whiting, P., Rutjies, A., Reitsma, J., Bossuyt, P. \& Klejnen, J. 2003. The development of QUADAS: A tool for the quality assessment of studies of diagnostic accuracy included in systematic reviews. BMC medical research methodology, 3(25).

[29] De Bruin, T., Freeze, R., Kaulkarni, U. \& Rosemann, M. 2005. Understanding the main phases of developing a maturity assessment model. In: Australasian Conference on Information Systems (ACIS). Sydney, Australia.

[30] Oxford University Press. 2017. Domain. [Online]. Available: https://en.oxforddictionaries.com/definition/domain. [Accessed: 25-Apr-2017]. 


\section{APPENDIX A}

1 Description of the innovation adoption process (combined with Table 2 to develop the user interface)

Table 1: Description of the innovation adoption process using five domains

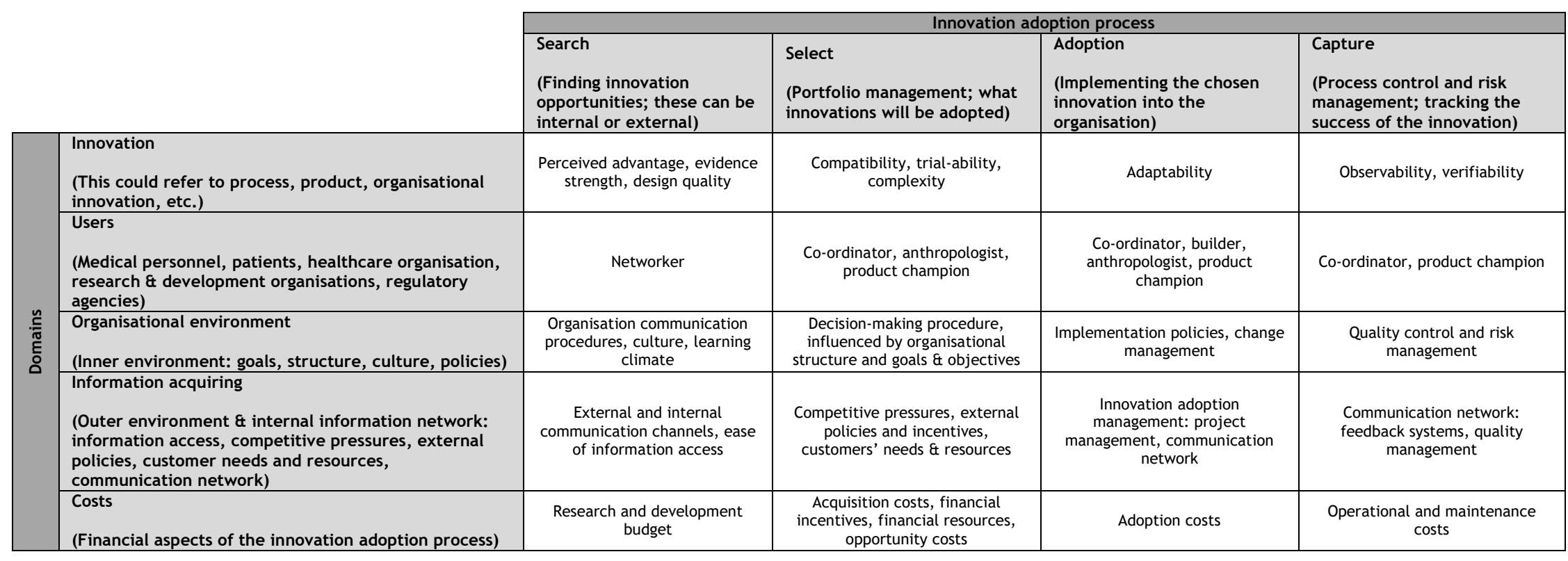


2 Specific domain maturity capability (combined with Table 1 to develop the user interface)

Table 2: Process capability maturity statements per level

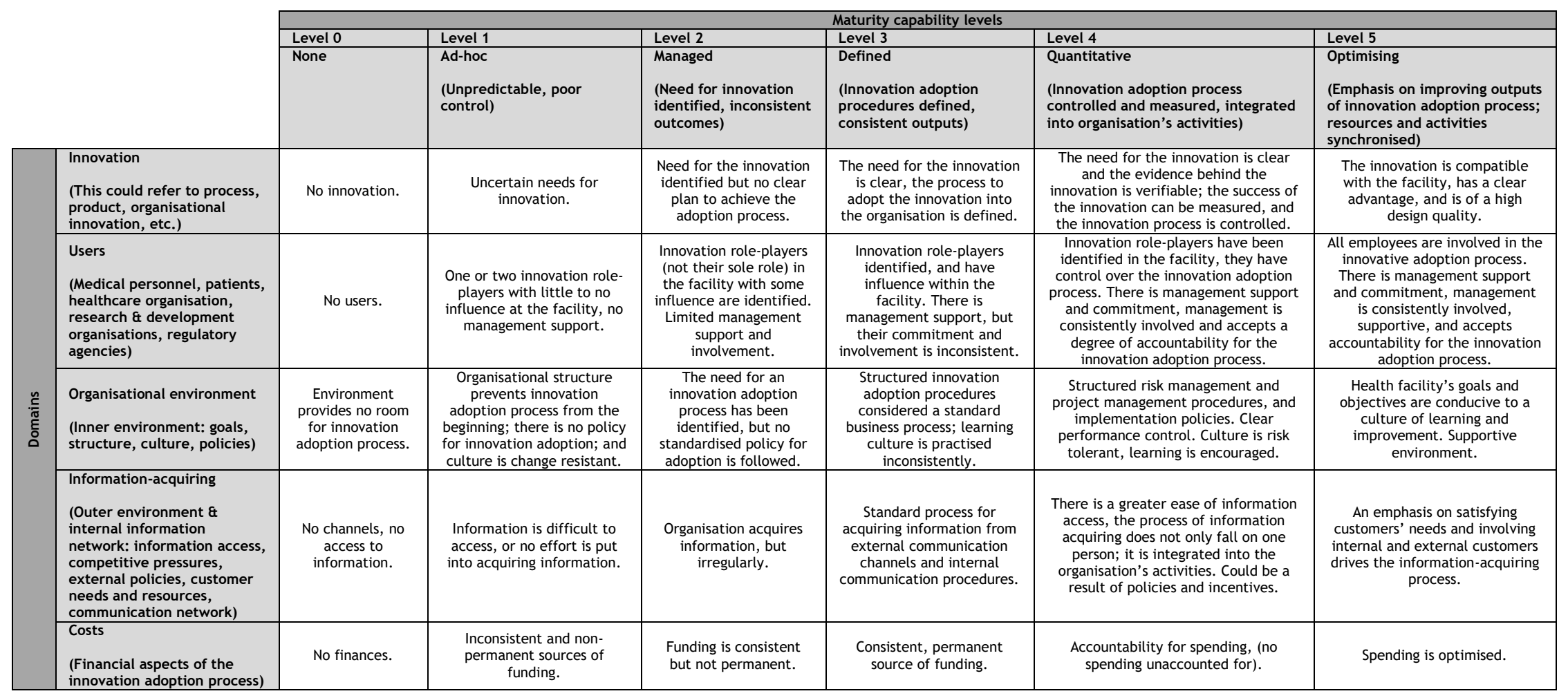


Table 3: Innovation adoption process maturity capability for the innovation's characteristics domain

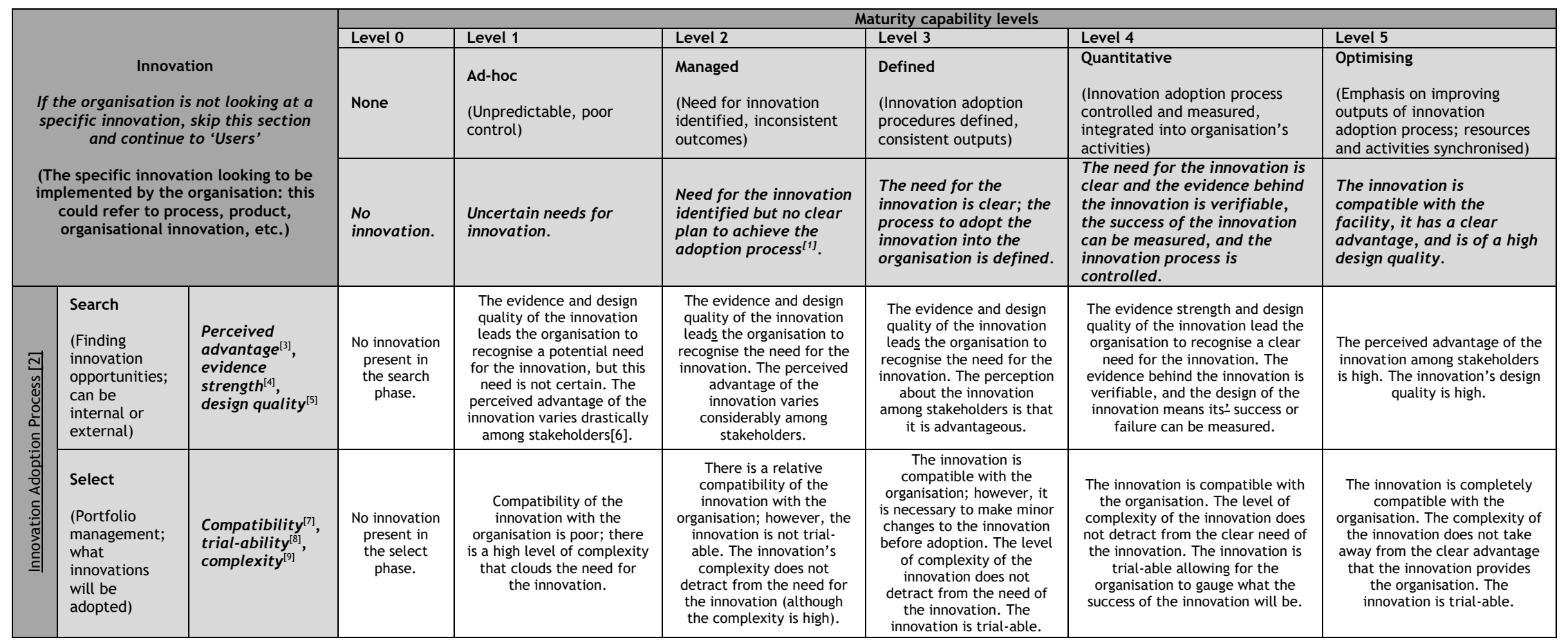

This process includes the phases of innovation adoption: search, select, adoption, capture.

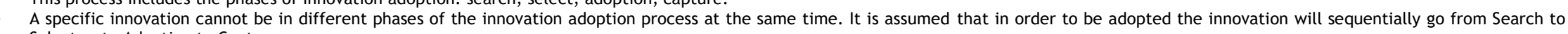
Select to Adoption to Capture.

3 Perceived advantage refers to the relative advantage that adopting this specific innovation will have for the organisation.

4 Evidence strength refers to the evidence supporting the innovation, the strength is the extent to which the evidence is sound and convincing.

5 Design quality refers to the quality of the actual innovation's design, including how the innovation is presented.

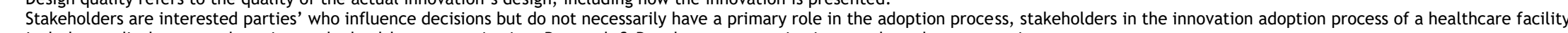
include: medical personnel, patients, the healthcare organisation, Research \& Development organisations, and regulatory agencies.

7 Compatibility refers to how well the innovation, that will potentially be adopted, fits into the organisation's existing systems (the technical, physical and organisational systems).

8 Trial-ability refers to how easily the innovation can be tested or prototyped at the organisation before being implemented.

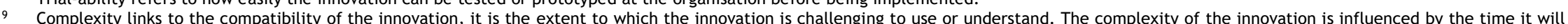

take to adopt the innovation, the steps required to adopt the innovation, the scope that the innovation covers, how radical and disruptive the innovation is, and how intricate the innovation is. 


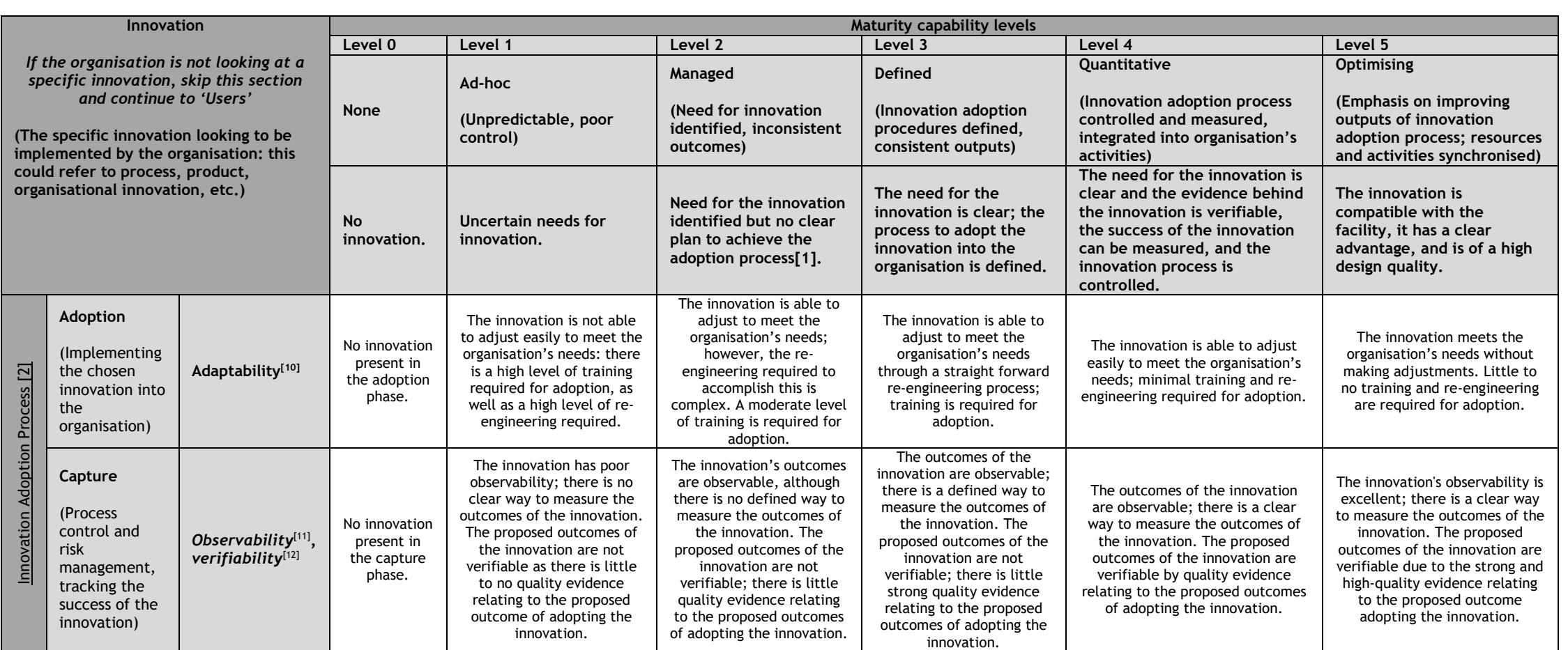

This process includes the phases of innovation adoption: search, select, adoption, capture

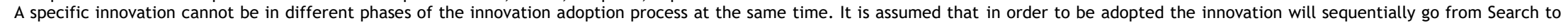
Select to Adoption to Capture.

3 Perceived advantage refers to the relative advantage that adopting this specific innovation will have for the organisation.

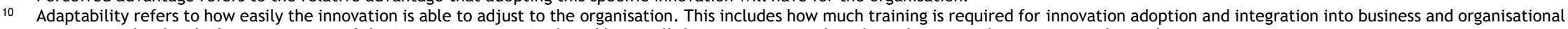
processes, what level of re-engineering of the innovation is required, and how well the innovation can be adapted to meet the organisation's needs.

11 Observability refers to how easily the adopted innovations' outcomes can be observed and measured by the organisation.

12 Verifiability refers to the evidence strength and quality relating to the proposed outcome of adopting the innovation. 
Table 4: Innovation adoption process maturity capability for the users' domain

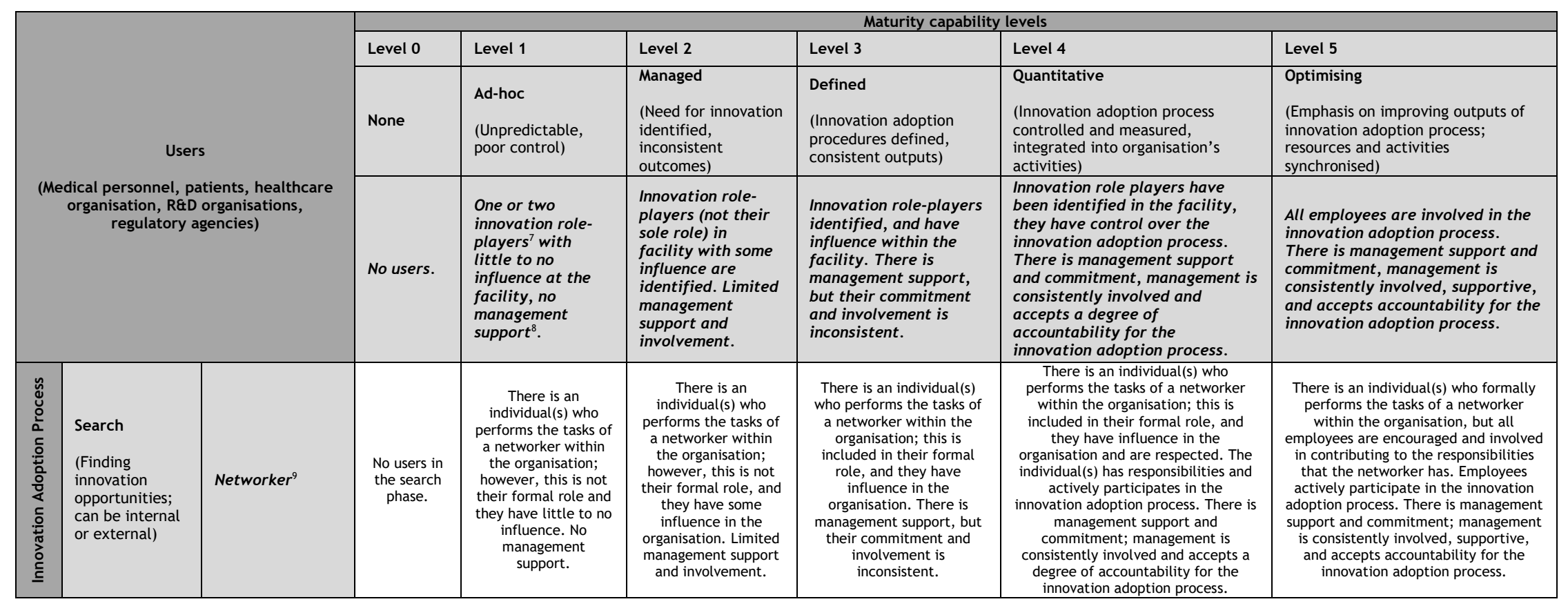

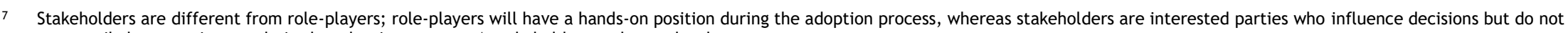
necessarily have a primary role in the adoption process. A stakeholder can be a role-player.

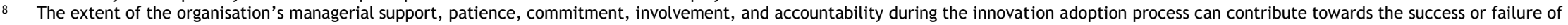
an innovation adoption process. Managers have significant influence over the decision to adopt an innovation, even though they are often not the intended users.

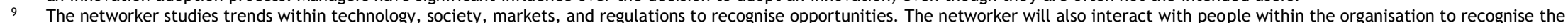
internal needs and opportunities. The networker is responsible for creating connections with external organisations, or with individuals who have corresponding objectives. 


\begin{tabular}{|c|c|c|c|c|c|c|c|}
\hline $\begin{array}{l}\text { Select } \\
\text { (Portfolio } \\
\text { management; } \\
\text { what } \\
\text { innovations will } \\
\text { be adopted) }\end{array}$ & $\begin{array}{l}\text { Co-ordinator }{ }^{10}, \\
\text { anthropologist }^{11}, \\
\text { product } \\
\text { champion }^{12}\end{array}$ & $\begin{array}{l}\text { No users in } \\
\text { the select } \\
\text { phase. }\end{array}$ & $\begin{array}{l}\text { There are individuals } \\
\text { who perform the task } \\
\text { of co-ordinator, } \\
\text { anthropologist, and } \\
\text { product champion } \\
\text { within the } \\
\text { organisation; } \\
\text { however, this is not } \\
\text { their formal role and } \\
\text { they have little to no } \\
\text { influence. No } \\
\text { management } \\
\text { support. }\end{array}$ & $\begin{array}{l}\text { There are individuals } \\
\text { who perform the task } \\
\text { of a co-ordinator, } \\
\text { anthropologist, and } \\
\text { product champion } \\
\text { within the } \\
\text { organisation; } \\
\text { however, this is not } \\
\text { their formal role, } \\
\text { though they have } \\
\text { some influence in the } \\
\text { organisation. Limited } \\
\text { management support } \\
\text { and involvement. }\end{array}$ & $\begin{array}{l}\text { There are individuals who } \\
\text { perform the task of a co- } \\
\text { ordinator, anthropologist, } \\
\text { and product champion } \\
\text { within the organisation; } \\
\text { this is included in their } \\
\text { formal role, and they have } \\
\text { influence in the } \\
\text { organisation. There is } \\
\text { management support, but } \\
\text { their commitment and } \\
\text { involvement is } \\
\text { inconsistent. }\end{array}$ & $\begin{array}{l}\text { There are individuals who perform } \\
\text { the task of a co-ordinator, } \\
\text { anthropologist, and product } \\
\text { champion within the organisation; } \\
\text { this is included in their formal role, } \\
\text { and they have influence in the } \\
\text { organisation and are respected. The } \\
\text { individuals have responsibilities and } \\
\text { actively participate in the innovation } \\
\text { adoption process. There is } \\
\text { management support and } \\
\text { commitment; management is } \\
\text { consistently involved and accepts a } \\
\text { degree of accountability for the } \\
\text { innovation adoption process. }\end{array}$ & $\begin{array}{l}\text { There are individuals who formally } \\
\text { perform the task of a co-ordinator, } \\
\text { anthropologist, and product champion } \\
\text { within the organisation, but all } \\
\text { employees are encouraged and involved } \\
\text { in contributing to the responsibilities } \\
\text { that the co-ordinator, anthropologist, } \\
\text { and product champion has. Employees } \\
\text { actively participate in the innovation } \\
\text { adoption process. There is management } \\
\text { support and commitment. Management } \\
\text { is consistently involved, supportive, } \\
\text { and accepts accountability for the } \\
\text { innovation adoption process. }\end{array}$ \\
\hline $\begin{array}{l}\text { Adoption } \\
\text { (Implementing } \\
\text { the chosen } \\
\text { innovation into } \\
\text { the } \\
\text { organisation) }\end{array}$ & $\begin{array}{l}\text { Co-ordinator, } \\
\text { builder }^{13} \text {, } \\
\text { anthropologist, }_{\text {product }} \\
\text { champion }\end{array}$ & $\begin{array}{l}\text { No users in } \\
\text { the } \\
\text { adoption } \\
\text { phase. }\end{array}$ & $\begin{array}{l}\text { There are individuals } \\
\text { who perform the task } \\
\text { of a co-ordinator, } \\
\text { builder, } \\
\text { anthropologist, and } \\
\text { product champion } \\
\text { within the } \\
\text { organisation; } \\
\text { however, this is not } \\
\text { their formal role and } \\
\text { they have little to no } \\
\text { influence. No } \\
\text { management } \\
\text { support. }\end{array}$ & $\begin{array}{l}\text { There are individuals } \\
\text { who perform the task } \\
\text { of a co-ordinator, } \\
\text { builder, } \\
\text { anthropologist, and } \\
\text { product champion } \\
\text { within the } \\
\text { organisation; } \\
\text { however, this is not } \\
\text { their formal role. } \\
\text { They have some } \\
\text { influence in the } \\
\text { organisation. Limited } \\
\text { management support } \\
\text { and involvement. }\end{array}$ & $\begin{array}{l}\text { There are individuals who } \\
\text { perform the task of a co- } \\
\text { ordinator, builder, } \\
\text { anthropologist, and } \\
\text { product champion within } \\
\text { the organisation. This is } \\
\text { included in their formal } \\
\text { role, and they have } \\
\text { influence in the } \\
\text { organisation. There is } \\
\text { management support, but } \\
\text { their commitment and } \\
\text { involvement is } \\
\text { inconsistent. }\end{array}$ & $\begin{array}{l}\text { There are individuals who perform } \\
\text { the task of a co-ordinator, builder, } \\
\text { anthropologist, and product } \\
\text { champion within the organisation. } \\
\text { This is included in their formal role, } \\
\text { and they have influence in the } \\
\text { organisation and are respected. The } \\
\text { individuals have responsibilities and } \\
\text { actively participate in the innovation } \\
\text { adoption process. There is } \\
\text { management support and } \\
\text { commitment, and management is } \\
\text { consistently involved and accepts a } \\
\text { degree of accountability for the } \\
\text { innovation adoption process. }\end{array}$ & $\begin{array}{l}\text { There are individuals who formally } \\
\text { perform the task of a co-ordinator, } \\
\text { builder, anthropologist, and product } \\
\text { champion within the organisation, but } \\
\text { all employees are encouraged and } \\
\text { involved in contributing to the } \\
\text { responsibilities that the co-ordinator, } \\
\text { builder, anthropologist, and product } \\
\text { champion have. Employees actively } \\
\text { participate in the innovation adoption } \\
\text { process. There is management support } \\
\text { and commitment, and management is } \\
\text { consistently involved, supportive, and } \\
\text { accepts accountability for the } \\
\text { innovation adoption process. }\end{array}$ \\
\hline $\begin{array}{l}\text { Capture } \\
\text { (Process control } \\
\text { and risk } \\
\text { management; } \\
\text { tracking the } \\
\text { success of the } \\
\text { innovation) }\end{array}$ & $\begin{array}{l}\text { Co-ordinator, } \\
\text { product } \\
\text { champion }\end{array}$ & $\begin{array}{l}\text { No users in } \\
\text { the capture } \\
\text { phase. }\end{array}$ & $\begin{array}{l}\text { There are individuals } \\
\text { who perform the task } \\
\text { of co-ordinator and } \\
\text { product champion } \\
\text { within the } \\
\text { organisation; } \\
\text { however, this is not } \\
\text { their formal role and } \\
\text { they have little to no } \\
\text { influence. No } \\
\text { management } \\
\text { support. }\end{array}$ & $\begin{array}{l}\text { There are individuals } \\
\text { who perform the task } \\
\text { of co-ordinator and } \\
\text { product champion } \\
\text { within the } \\
\text { organisation; } \\
\text { however, this is not } \\
\text { their formal role. } \\
\text { They have some } \\
\text { influence in the } \\
\text { organisation. Limited } \\
\text { management support } \\
\text { and involvement. }\end{array}$ & $\begin{array}{l}\text { There are individuals who } \\
\text { perform the task of co- } \\
\text { ordinator and product } \\
\text { champion within the } \\
\text { organisation. This is } \\
\text { included in their formal } \\
\text { role, and they have } \\
\text { influence in the } \\
\text { organisation. There is } \\
\text { management support, but } \\
\text { their commitment and } \\
\text { involvement is } \\
\text { inconsistent. }\end{array}$ & $\begin{array}{l}\text { There are individuals who perform } \\
\text { the task of co-ordinator and product } \\
\text { champion within the organisation. } \\
\text { This is included in their formal role, } \\
\text { and they have influence in the } \\
\text { organisation and are respected. The } \\
\text { individuals have responsibilities and } \\
\text { actively participate in the innovation } \\
\text { adoption process. There is } \\
\text { management support and } \\
\text { commitment, and management is } \\
\text { consistently involved and accepts a } \\
\text { degree of accountability for the } \\
\text { innovation adoption process. }\end{array}$ & $\begin{array}{l}\text { There are individuals who formally } \\
\text { perform the task of co-ordinator and } \\
\text { product champion within the } \\
\text { organisation, but all employees are } \\
\text { encouraged and involved in } \\
\text { contributing to the responsibilities that } \\
\text { the co-ordinator and product champion } \\
\text { have. Employees actively participate in } \\
\text { the innovation adoption process. There } \\
\text { is management support and } \\
\text { commitment, and management is } \\
\text { consistently involved, supportive, and } \\
\text { accepts accountability for the } \\
\text { innovation adoption process. }\end{array}$ \\
\hline
\end{tabular}

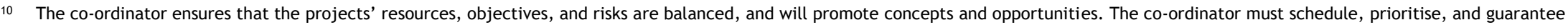
project completion through overcoming obstacles faced.

1 he anthropologist must have an understanding of people's interactions (both emotional and physical) with services, products, their environment, and with other people. The anthropologist can anticipate stakeholders' needs and is able to influence people's attitudes and behaviours.

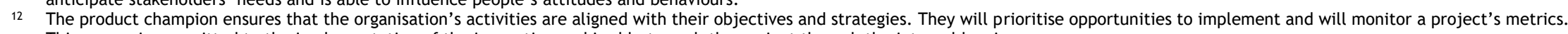
This person is committed to the implementation of the innovation and is able to push the project through the internal barriers.

13 The builder creates, demonstrates, and defines tangible concepts; the builder will ensure the product or service is ready to be supplied to the customer. 
Table 5: Innovation adoption process maturity capability for the organisational environment domain

\begin{tabular}{|c|c|c|c|c|c|c|c|c|}
\hline & & & & & & rity capability levels & & \\
\hline & & & Level 0 & Level 1 & Level 2 & Level 3 & Level 4 & Level 5 \\
\hline & Organisation & environment & None & $\begin{array}{l}\text { Ad-hoc } \\
\text { (Unpredictable, poor } \\
\text { control) }\end{array}$ & $\begin{array}{l}\text { Managed } \\
\text { (Need for innovation } \\
\text { identified; inconsistent } \\
\text { outcomes) }\end{array}$ & $\begin{array}{l}\text { Defined } \\
\text { (Innovation adoption } \\
\text { procedures defined; } \\
\text { consistent outputs) }\end{array}$ & $\begin{array}{l}\text { Quantitative } \\
\text { (Innovation adoption } \\
\text { process controlled and } \\
\text { measured; integrated into } \\
\text { organisation's activities) }\end{array}$ & $\begin{array}{l}\text { Optimising } \\
\text { (Emphasis on improving outputs } \\
\text { of innovation adoption process; } \\
\text { resources and activities } \\
\text { synchronised) }\end{array}$ \\
\hline & $\begin{array}{r}\text { inner environn } \\
\text { cultu }\end{array}$ & (s) & $\begin{array}{l}\text { Environment } \\
\text { provides no } \\
\text { room for } \\
\text { innovation } \\
\text { adoption } \\
\text { process. }\end{array}$ & $\begin{array}{l}\text { Organisational } \\
\text { structure prevents } \\
\text { innovation adoption } \\
\text { process from the } \\
\text { beginning; there is no } \\
\text { policy for innovation } \\
\text { adoption, and culture } \\
{\text { is change resistant }{ }^{14} \text {. }}^{\text {. }} \text {. }\end{array}$ & $\begin{array}{l}\text { The need for an } \\
\text { innovation adoption } \\
\text { process has been } \\
\text { identified, but no } \\
\text { standardised policy for } \\
\text { adoption is followed. }\end{array}$ & $\begin{array}{l}\text { Structured innovation } \\
\text { adoption procedures } \\
\text { are considered a } \\
\text { standard business } \\
\text { process; learning } \\
\text { culture is practised } \\
\text { inconsistently. }\end{array}$ & $\begin{array}{l}\text { Structured risk } \\
\text { management } \\
\text { procedures, project } \\
\text { management } \\
\text { procedures, and } \\
\text { implementation } \\
\text { policies. Clear } \\
\text { performance control. } \\
\text { Culture is risk tolerant; } \\
\text { learning is encouraged. }\end{array}$ & $\begin{array}{l}\text { Health facility's goals and } \\
\text { objectives are conducive to a } \\
\text { culture of learning and } \\
\text { improvement. Supportive } \\
\text { environment. }\end{array}$ \\
\hline 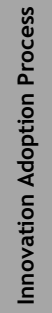 & $\begin{array}{l}\text { Search } \\
\text { (Finding } \\
\text { innovation } \\
\text { opportunities; } \\
\text { can be } \\
\text { internal or } \\
\text { external) }\end{array}$ & $\begin{array}{l}\text { Organisation } \\
\text { communication } \\
\text { procedures }^{15}, \\
\text { culture }^{16}, \text { learning } \\
\text { climate }^{17}\end{array}$ & $\begin{array}{c}\text { The } \\
\text { organisational } \\
\text { environment is } \\
\text { not conducive } \\
\text { to searching for } \\
\text { innovations to } \\
\text { adopt. }\end{array}$ & $\begin{array}{l}\text { The organisation's } \\
\text { communication } \\
\text { procedures are poorly } \\
\text { controlled; there is a } \\
\text { change resistant culture } \\
\text { within the organisation. } \\
\text { The climate within the } \\
\text { organisation is risk } \\
\text { averse and does not } \\
\text { promote learning. }\end{array}$ & $\begin{array}{l}\text { The organisation's } \\
\text { communication procedures } \\
\text { are controlled but the } \\
\text { procedures are not } \\
\text { standardised. There is a } \\
\text { change resistant culture } \\
\text { within the organisation. The } \\
\text { climate within the } \\
\text { organisation is risk averse; } \\
\text { however, there is a culture } \\
\text { of learning that is } \\
\text { inconsistently promoted. }\end{array}$ & $\begin{array}{l}\text { The organisation's } \\
\text { communication } \\
\text { procedures are controlled } \\
\text { and standardised. An } \\
\text { organisational culture of } \\
\text { learning is practiced. } \\
\text { There is a level of } \\
\text { tolerance towards risk. }\end{array}$ & $\begin{array}{l}\text { The organisation's } \\
\text { communication procedures } \\
\text { are well controlled. The } \\
\text { organisational culture is risk } \\
\text { tolerant; learning is } \\
\text { encouraged. }\end{array}$ & $\begin{array}{l}\text { The organisation's communication } \\
\text { procedures are excellently } \\
\text { controlled. The organisational } \\
\text { culture is tolerant to change, and } \\
\text { the climate within the } \\
\text { organisation is supportive and } \\
\text { promotes learning. }\end{array}$ \\
\hline
\end{tabular}

14 Change resistant: Behavioural barriers within an organisation consist of decision-makers' motivations, priorities, rationality, and inclination towards risk and change.

15 Communication procedures refer to the organisation's established external and internal communication policies that are enforced and followed throughout the organisation.

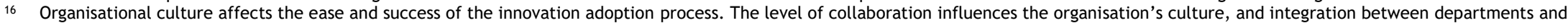
personnel, by how tolerant to risk the organisation is, and whether a climate of learning is encouraged. The behaviours of the users in the organisation also influence the organisational culture.

Behaviours include preconceived beliefs about the innovation, resistance to change, and the attitude towards risk. 


\begin{tabular}{|c|c|c|c|c|c|c|c|}
\hline $\begin{array}{l}\text { Select } \\
\text { (Portfolio } \\
\text { management; } \\
\text { what } \\
\text { innovations } \\
\text { will be } \\
\text { adopted) }\end{array}$ & $\begin{array}{l}\text { Decision-making } \\
\text { procedure }{ }^{18} ; \\
\text { influenced by } \\
\text { organisational }^{10} \\
\text { structure }^{19} \text { and } \\
\text { goals and } \\
\text { objectives }^{20}\end{array}$ & $\begin{array}{l}\text { The } \\
\text { organisational } \\
\text { environment is } \\
\text { not conducive } \\
\text { to selecting } \\
\text { innovations. }\end{array}$ & $\begin{array}{c}\text { Decision-making } \\
\text { procedures are poorly } \\
\text { controlled and structural } \\
\text { aspects of the } \\
\text { organisation prevent an } \\
\text { innovation from being } \\
\text { selected. The goals and } \\
\text { objectives of the } \\
\text { organisation are not } \\
\text { communicated clearly, } \\
\text { and do not encourage } \\
\text { innovation. }\end{array}$ & $\begin{array}{l}\text { Decision-making procedures } \\
\text { are poorly controlled. The } \\
\text { organisational structure does } \\
\text { not prevent an innovation } \\
\text { from being selected, } \\
\text { although it potentially } \\
\text { creates further obstacles to } \\
\text { selecting an innovation. The } \\
\text { goals and objectives of the } \\
\text { organisation are not } \\
\text { communicated clearly, } \\
\text { although they do encourage } \\
\text { innovation adoptions. }\end{array}$ & $\begin{array}{l}\text { Decision-making } \\
\text { procedures are controlled. } \\
\text { The organisational } \\
\text { structure does not impede } \\
\text { the selection of an } \\
\text { innovation. The goals and } \\
\text { objectives of the } \\
\text { organisation are } \\
\text { communicated and } \\
\text { encourage innovation } \\
\text { adoptions. }\end{array}$ & $\begin{array}{l}\text { Decision-making procedures } \\
\text { are well controlled. The } \\
\text { organisational structure } \\
\text { does not impede the } \\
\text { selection of an innovation. } \\
\text { The goals and objectives of } \\
\text { the organisation are clearly } \\
\text { communicated, and } \\
\text { stimulate innovation } \\
\text { adoptions. }\end{array}$ & $\begin{array}{l}\text { Decision-making procedures are } \\
\text { controlled effectively and the } \\
\text { organisational structure is not a } \\
\text { barrier to selecting an innovation } \\
\text { for adoption. The goals and } \\
\text { objectives of the organisation are } \\
\text { communicated clearly and } \\
\text { understood by all employees in } \\
\text { the organisation. The goals and } \\
\text { objectives of the organisation } \\
\text { include innovation and encourage } \\
\text { the innovation adoption process } \\
\text { to thrive. }\end{array}$ \\
\hline $\begin{array}{l}\text { Adoption } \\
\text { (Implementing } \\
\text { the chosen } \\
\text { innovation } \\
\text { into the } \\
\text { organisation) }\end{array}$ & $\begin{array}{l}\text { Implementation } \\
\text { policies }^{21} ; \text { change }^{22} \\
\text { management }^{22}\end{array}$ & $\begin{array}{l}\text { The } \\
\text { organisational } \\
\text { environment is } \\
\text { not conducive } \\
\text { to adopting } \\
\text { innovations. }\end{array}$ & $\begin{array}{l}\text { Implementation is poorly } \\
\text { controlled. There is no } \\
\text { change management } \\
\text { procedure. }\end{array}$ & $\begin{array}{l}\text { Implementation is controlled } \\
\text { but there are no formal } \\
\text { implementation polices. The } \\
\text { need for change management } \\
\text { is recognised; the change } \\
\text { management procedure is } \\
\text { sporadically practised and } \\
\text { not formalised. }\end{array}$ & $\begin{array}{l}\text { Implementation is } \\
\text { controlled, and there are } \\
\text { formal implementation } \\
\text { polices. The change } \\
\text { management procedure is } \\
\text { formalised; however, it is } \\
\text { still sporadically } \\
\text { practiced. }\end{array}$ & $\begin{array}{l}\text { Implementation is } \\
\text { controlled; there are } \\
\text { formal, structured } \\
\text { implementation polices. } \\
\text { The change management } \\
\text { procedure is formalised and } \\
\text { is practised regularly. }\end{array}$ & $\begin{array}{l}\text { Implementation is excellently } \\
\text { controlled; there are formalised } \\
\text { implementation polices. Change } \\
\text { management is a formal policy } \\
\text { that is continuously practised and } \\
\text { controlled. }\end{array}$ \\
\hline $\begin{array}{l}\text { Capture } \\
\text { (Process } \\
\text { control and } \\
\text { risk } \\
\text { management; } \\
\text { tracking the } \\
\text { success of the } \\
\text { innovation) }\end{array}$ & $\begin{array}{l}\text { Quality control }{ }^{23} \\
\text { and risk } \\
\text { management }^{24}\end{array}$ & $\begin{array}{l}\text { The } \\
\text { organisational } \\
\text { environment is } \\
\text { not conducive } \\
\text { to capturing } \\
\text { innovations. }\end{array}$ & $\begin{array}{l}\text { Quality assessments are } \\
\text { poorly controlled and } \\
\text { sporadically carried out. } \\
\text { There is no formal risk } \\
\text { management procedure } \\
\text { in the organisation. }\end{array}$ & $\begin{array}{l}\text { Quality assessments are } \\
\text { controlled but there are no } \\
\text { formal quality management } \\
\text { procedures. The need for risk } \\
\text { management is recognised; } \\
\text { risk management is } \\
\text { sporadically practised and } \\
\text { not formalised. }\end{array}$ & $\begin{array}{l}\text { Quality assessments are } \\
\text { controlled, there are } \\
\text { formal quality } \\
\text { management policies. The } \\
\text { risk management } \\
\text { procedure is formalised; } \\
\text { however, it is still } \\
\text { sporadically practiced. }\end{array}$ & $\begin{array}{l}\text { Quality assessments are } \\
\text { controlled; there are } \\
\text { formal, structured quality } \\
\text { management policies. The } \\
\text { risk management procedure } \\
\text { is formalised and is } \\
\text { practised on a regular basis. }\end{array}$ & $\begin{array}{l}\text { Quality assessments are } \\
\text { excellently controlled; there are } \\
\text { formalised quality management } \\
\text { policies. Risk management is a } \\
\text { formal policy that is continuously } \\
\text { practised and controlled. }\end{array}$ \\
\hline
\end{tabular}

18 An organisation must have a structured, established decision-making process and effective management of this decision-making procedure.

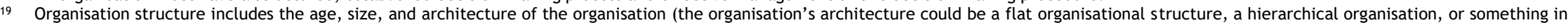
between the two). The organisation includes the healthcare facility and the government Department of Health.

20 Goals and objectives: are these goals clearly communicated, and are they conducive to a positive innovation adoption environment within the healthcare organisation?

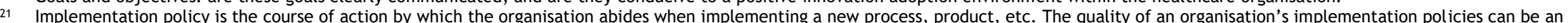
indication of the success or failure to adopt an innovation.

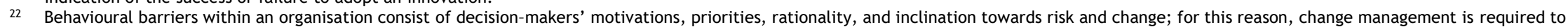
control the change process, and to minimise resistance as far as possible.

23 Quality control policies will minimise the potential risks of adopting a new innovation, meaning that there will be a higher chance of innovation adoption success.

24 Risk management is required to predict and evaluate potential risks, and to put procedures in place that control and mitigate the identified risks as far as possible. 
Table 6: Innovation adoption process maturity capability for the information acquisition domain

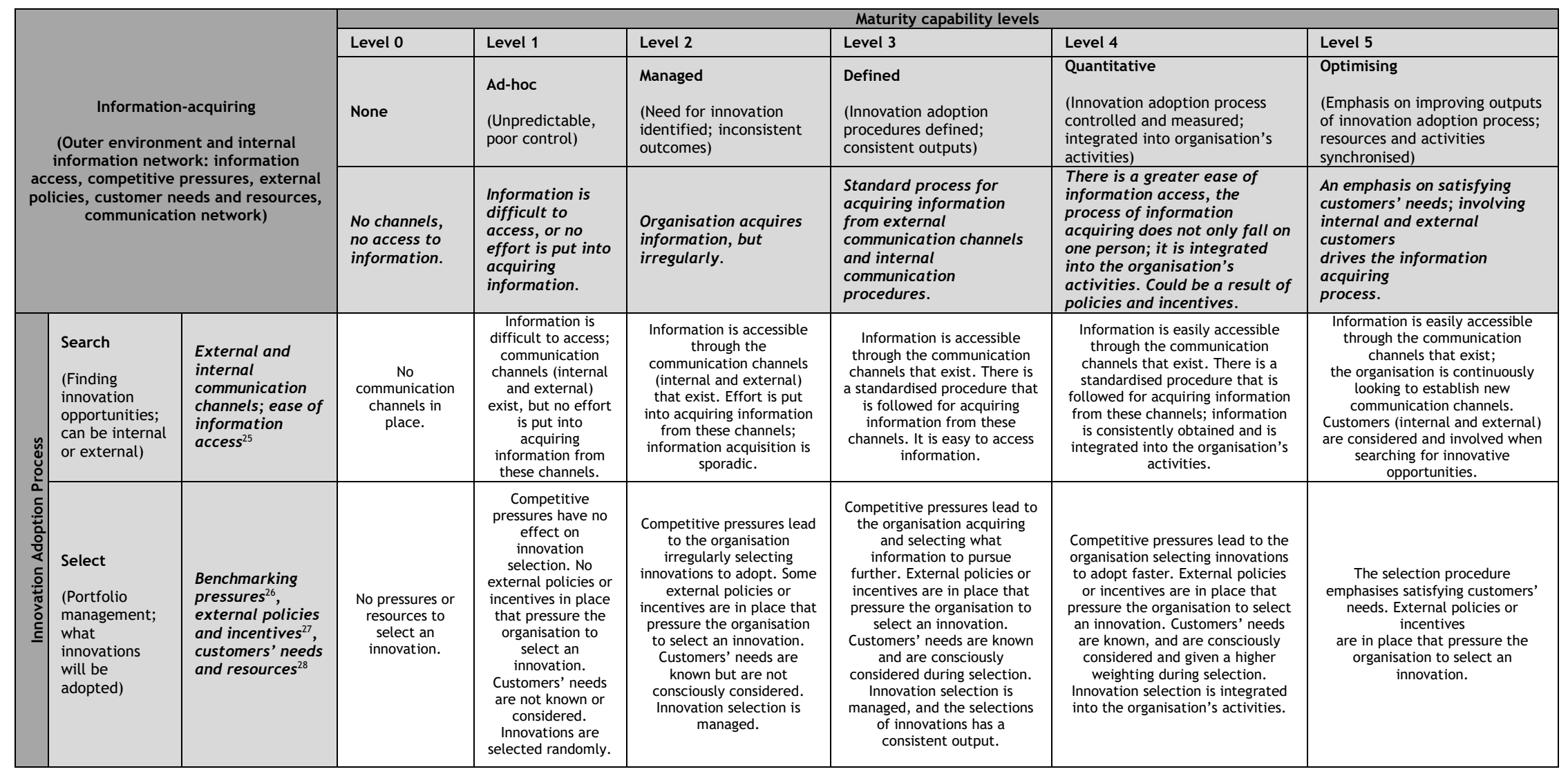

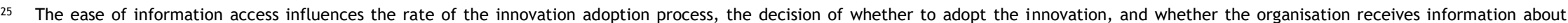
available innovations to address current challenges faced by the organisation.

26 Benchmarking pressure is a result of a competing organisation or well-respected organisation adopting a particular innovation compelling the organisation being considered to do the same.

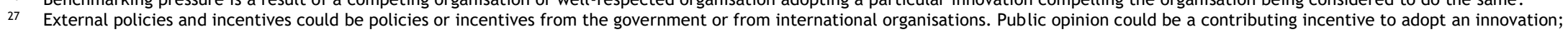
incentives could be monetary.

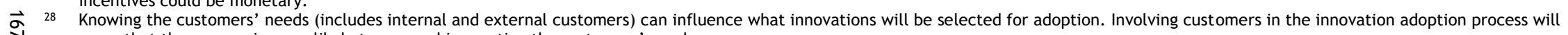
mean that the process is more likely to succeed in meeting the customers' needs. 


\begin{tabular}{|c|c|c|c|c|c|c|c|}
\hline $\begin{array}{l}\text { Adoption } \\
\text { (Implementing } \\
\text { the chosen } \\
\text { innovation into } \\
\text { the } \\
\text { organisation) }\end{array}$ & $\begin{array}{l}\text { Innovation } \\
\text { adoption } \\
\text { management } \\
\text { policies; project } \\
\text { management } \\
\text { communication }^{29} \\
\text { network }^{30}\end{array}$ & $\begin{array}{l}\text { No } \\
\text { communication } \\
\text { channels in } \\
\text { place; } \\
\text { innovation } \\
\text { adoption } \\
\text { management is } \\
\text { non-existent. }\end{array}$ & $\begin{array}{l}\text { The organisation's } \\
\text { internal } \\
\text { communication } \\
\text { network is not } \\
\text { effective, making } \\
\text { information } \\
\text { difficult to access. } \\
\text { Project } \\
\text { management } \\
\text { policies exist but } \\
\text { are poorly } \\
\text { controlled. }\end{array}$ & $\begin{array}{l}\text { The organisation's internal } \\
\text { communication network is } \\
\text { effective for transmitting } \\
\text { information about the } \\
\text { adoption process. Project } \\
\text { management policies exist } \\
\text { and are managed; } \\
\text { however, the outcomes are } \\
\text { inconsistent. }\end{array}$ & $\begin{array}{l}\text { The organisation's internal } \\
\text { communication network is } \\
\text { effective for transmitting } \\
\text { information about the } \\
\text { adoption process; the internal } \\
\text { communication network has } \\
\text { been standardised. Project } \\
\text { management policies exist } \\
\text { and are managed; the } \\
\text { outcomes of adoption are } \\
\text { consistent. }\end{array}$ & $\begin{array}{l}\text { The organisation's internal } \\
\text { communication network is } \\
\text { effective for transmitting } \\
\text { information about the adoption } \\
\text { process; the internal } \\
\text { communication network has been } \\
\text { integrated into the organisation's } \\
\text { activities. Project management } \\
\text { policies are managed; the } \\
\text { outcomes are consistent and } \\
\text { measurable. }\end{array}$ & $\begin{array}{l}\text { The organisation's internal } \\
\text { communication } \\
\text { network is optimised and provides } \\
\text { a channel for internal customers } \\
\text { to offer input during the adoption } \\
\text { stage of the process. There is } \\
\text { greater ease of involving } \\
\text { customers } \\
\text { in the adoption stage of the } \\
\text { process. } \\
\text { and } \\
\text { Project management policies exist } \\
\text { are optimally managed. }\end{array}$ \\
\hline $\begin{array}{l}\text { Capture } \\
\text { (Process } \\
\text { control and } \\
\text { risk } \\
\text { management; } \\
\text { tracking the } \\
\text { success of the } \\
\text { innovation) }\end{array}$ & $\begin{array}{l}\text { Communication } \\
\text { network: } \\
\text { feedback } \\
\text { systems, quality } \\
\text { management }{ }^{31}\end{array}$ & $\begin{array}{l}\text { No } \\
\text { communication } \\
\text { channels in } \\
\text { place to capture } \\
\text { information } \\
\text { from the } \\
\text { innovation. }\end{array}$ & $\begin{array}{l}\text { The organisation's } \\
\text { internal } \\
\text { communication } \\
\text { network is not } \\
\text { effective; feedback } \\
\text { on the adopted } \\
\text { innovation is } \\
\text { difficult to access. } \\
\text { Quality } \\
\text { management } \\
\text { policies are not } \\
\text { communicated to } \\
\text { the appropriate } \\
\text { personnel. This } \\
\text { leads to poor } \\
\text { process control }\end{array}$ & $\begin{array}{l}\text { The organisation's internal } \\
\text { communication network } \\
\text { provides feedback about } \\
\text { the adopted innovation; } \\
\text { however, this happens } \\
\text { irregularly and is difficult } \\
\text { to access. Quality } \\
\text { management policies are } \\
\text { communicated to the } \\
\text { appropriate personnel; the } \\
\text { policies produce } \\
\text { inconsistent outcomes. }\end{array}$ & $\begin{array}{l}\text { The organisation's internal } \\
\text { communication network is } \\
\text { effective, feedback is a } \\
\text { standard practice within the } \\
\text { organisation. Quality } \\
\text { management policies are } \\
\text { communicated and practised } \\
\text { by the appropriate personnel. }\end{array}$ & $\begin{array}{l}\text { The organisation's internal } \\
\text { communication network is } \\
\text { effective; feedback on the } \\
\text { adopted innovation is easy to } \\
\text { access. Quality management } \\
\text { policies are well communicated } \\
\text { and practiced; the quality of the } \\
\text { adopted innovation is measurable. }\end{array}$ & $\begin{array}{l}\text { The organisation's internal } \\
\text { communication network } \\
\text { effectively } \\
\text { provides feedback on the status of } \\
\text { the adopted } \\
\text { innovation, allowing for optimal } \\
\text { control over the implemented } \\
\text { innovation. Quality management } \\
\text { policies are known and practised } \\
\text { by all personnel. }\end{array}$ \\
\hline
\end{tabular}

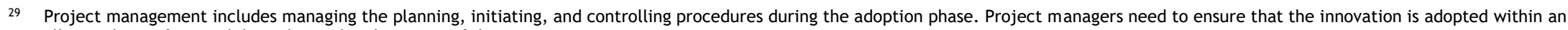
allocated time frame while realising the objectives of the innovation.

30 Communication network refers to the organisation's external and internal communication channels, and how well the organisation is networked with external organisations.

31 Quality management will minimise the potential risks of adopting a new innovation, meaning that there will be a higher chance of innovation adoption success. 
Table 7: Innovation adoption process maturity capability for the costs domain

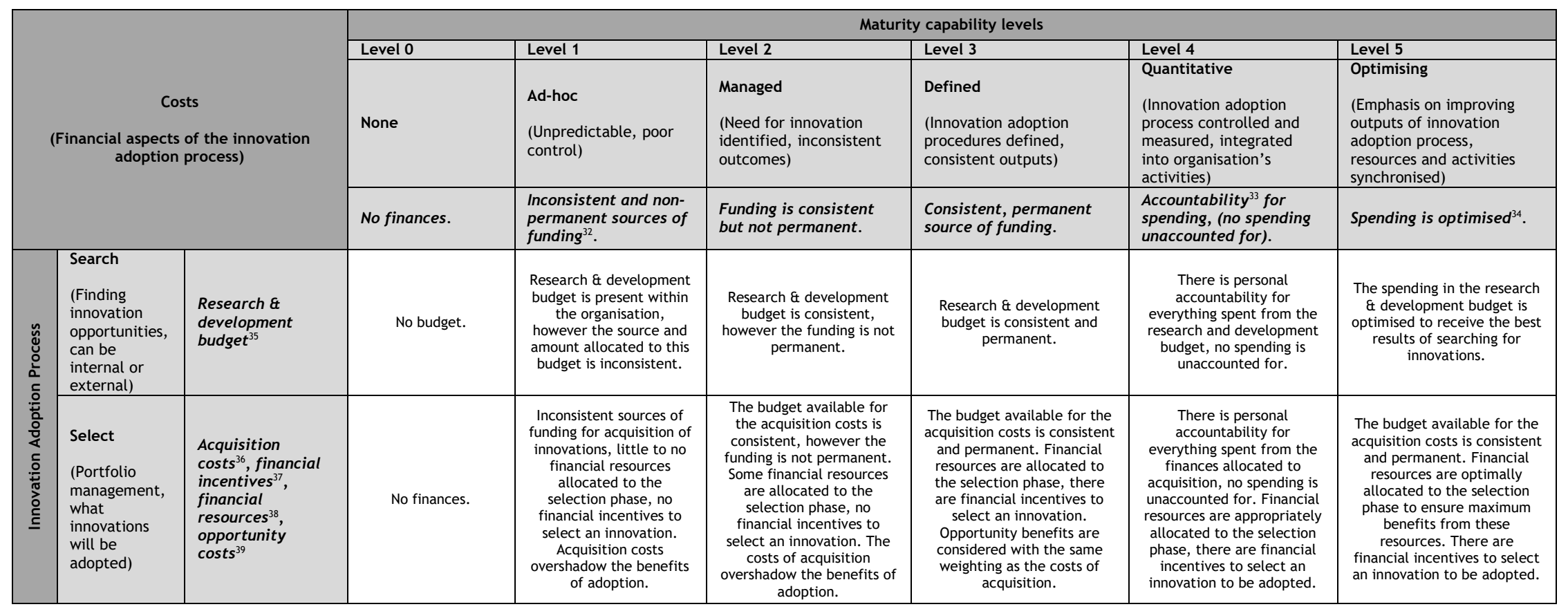

32 Funding consistency: financial resources available for the innovation may not be consistent, which will affect the innovation adoption process.

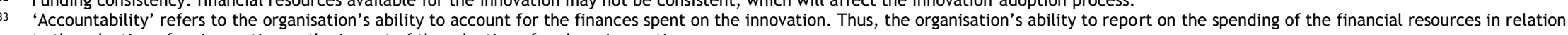
to the adoption of an innovation or the impact of the adoption of such an innovation.

34 'Optimised spending' refers to ensuring that spending is as effective as possible, getting the most value for the money spent.

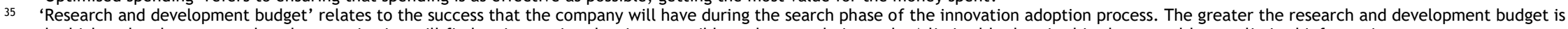
the higher the chances are that the organisation will find an innovation that is compatible and meets their needs. A limited budget in this phase would mean limited information access.

36 'Acquisition costs' relates to how much money the organisation will need to spend to attain the innovation (this is closely related to the research and development budget).

37 'Financial incentives' is an incentive provided as money in order to adopt an innovation.

38 Financial resources will not necessarily come from the organisation's budget, the financial resources could be funded by the government, by an NGO, by an international governing body etc.

'Opportunity costs' are those costs benefits which would be missed out on if the company failed to adopt an innovation. 


\begin{tabular}{|c|c|c|c|c|c|c|c|}
\hline $\begin{array}{l}\text { Adoption } \\
\text { (Implementing } \\
\text { the chosen } \\
\text { innovation } \\
\text { into the } \\
\text { organisation) }\end{array}$ & Adoption costs ${ }^{40}$ & No finances. & $\begin{array}{l}\text { Inconsistent sources of } \\
\text { funding for adoption of } \\
\text { an innovation. }\end{array}$ & $\begin{array}{l}\text { Consistent sources of } \\
\text { funding for adoption of an } \\
\text { innovation, however } \\
\text { funding is not permanent. }\end{array}$ & $\begin{array}{l}\text { Consistent and permanent } \\
\text { sources of funding for } \\
\text { adoption of an innovation. }\end{array}$ & $\begin{array}{l}\text { There is personal } \\
\text { accountability for } \\
\text { everything spent from the } \\
\text { finances allocated to } \\
\text { adoption, no spending is } \\
\text { unaccounted for. }\end{array}$ & $\begin{array}{l}\text { The budget available for the } \\
\text { adoption costs is consistent } \\
\text { and permanent. Financial } \\
\text { resources are optimally } \\
\text { allocated to the adoption } \\
\text { phase to ensure maximum } \\
\text { benefits from the } \\
\text { opportunity are realised. }\end{array}$ \\
\hline $\begin{array}{l}\text { Capture } \\
\text { (Process } \\
\text { control and } \\
\text { risk } \\
\text { management, } \\
\text { tracking the } \\
\text { success of the } \\
\text { innovation) }\end{array}$ & $\begin{array}{l}\text { Operational }\left.\right|^{41} \text { and } \\
\text { maintenance } \\
\text { costs }^{42}\end{array}$ & No finances. & $\begin{array}{l}\text { Inconsistent sources of } \\
\text { funding for operational } \\
\text { costs of innovations. } \\
\text { Little to no financial } \\
\text { resources allocated to } \\
\text { the maintenance of the } \\
\text { innovation. }\end{array}$ & $\begin{array}{l}\text { Consistent sources of } \\
\text { funding for operation and } \\
\text { maintenance of an } \\
\text { innovation, however } \\
\text { funding is not permanent. }\end{array}$ & $\begin{array}{l}\text { Consistent and permanent } \\
\text { sources of funding for } \\
\text { operation and maintenance } \\
\text { of an innovation. }\end{array}$ & $\begin{array}{l}\text { There is personal } \\
\text { accountability for } \\
\text { everthing spent from the } \\
\text { finances allocated to } \\
\text { operation and maintenance } \\
\text { of the innovation, no } \\
\text { spending is unaccounted } \\
\text { for. }\end{array}$ & $\begin{array}{l}\text { The budget available for the } \\
\text { operation and maintenance } \\
\text { costs is consistent and } \\
\text { permanent. Financial } \\
\text { resources are optimally } \\
\text { allocated to the capture } \\
\text { phase to ensure maximum } \\
\text { benefits from the } \\
\text { opportunity are realised. }\end{array}$ \\
\hline
\end{tabular}

40 'Adoption costs' include the initial investment required to adopt the innovation versus the opportunity costs of the innovation (benefits).

41 'Operational costs' are the finances required once the innovation has been adopted into the organisation to operate the innovation.

42 'Maintenance costs' are the finances required once the innovation has been adopted into the organisation to maintain the innovation. 